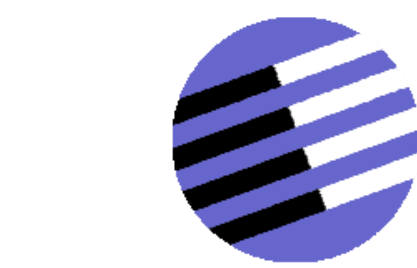

GOVERNANCE AND THE EFFICIENCY

OF ECONOMIC SYSTEMS

CESY

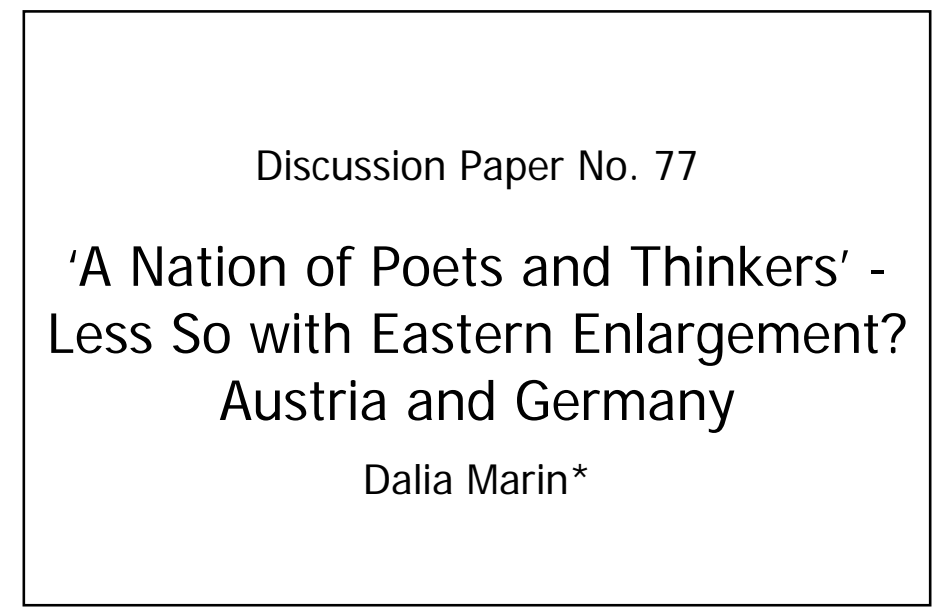

March 2004

*Dalia Marin, University of Munich

Financial support from the Deutsche Forschungsgemeinschaft through SFB/TR 15 is gratefully acknowledged. 


\title{
'A Nation of Poets and Thinkers' - Less So with Eastern Enlargement? Austria and Germany ${ }^{1}$
}

\author{
Dalia Marin \\ University of Munich
}

March, 2004

\begin{abstract}
Many people in the European Union fear that Eastern Enlargement will lead to major job losses. More recently, these fears about job losses have extended to high skill labor and IT jobs. The paper examines with new firm level data whether these fears are justified for the two neighboring countries of Eastern Enlargement Austria and Germany. I find that Eastern Enlargement leads to surprising small job losses, because jobs in Eastern Europe do not compete with jobs in Austria and Germany. Low cost jobs of affiliates in Eastern Europe help Austrian and German firms to stay competitive in an increasingly competitive environment. However, I also find that multinational firms in Austria and Germany are outsourcing the most skill intensive activities to Eastern Europe taking advantage of cheap abundant skilled labor in Eastern Europe. I find that the firms' outsourcing activities to Eastern Europe are a response to a human capital scarcity in Austria and Germany which has become particularly severe in the 1990s. Corporations' outsourcing of skill intensive firm activity to Eastern Europe has helped to ease the human capital crisis in both countries. I find that high skilled jobs transferred to Eastern Europe account for 10 percent of Germany's and 48 percent of Austria's supply of university graduates in the 1990s. I then discuss what can be done to address the skill exodus to Eastern Europe. I show that R\&D subsidies do not work in economies with a skill crisis and I suggest to liberalize the movement of high skill labor with Eastern Enlargement.
\end{abstract}

JEL Classification: F21, F23, J24, J31, L24, O3, P33

Keywords: human capital, intra-firm trade, multinationals and jobs, out-sourcing to Eastern Europe, R\&D policy

\footnotetext{
${ }^{1}$ I would like to thank Andzelika Lorentowicz, Alexander Protsenko, and Alexander Raubold for excellent research assistance. Financial support by the German Science Foundation under grants MA 1823/2-1, MA 1823/22, MA 1823/2-3, as well as through SFB/TR 15 and the Austrian Nationalbank are gratefully acknowledged.
} 


\section{Introduction}

Many people in the European Union fear that Eastern Enlargement leads to major job losses in the member countries, in particular in Austria and Germany as the two most important neighbors of Eastern Enlargement. More recently, in Germany these fears about job losses to the accession countries have extended to high skill labor and IT jobs. German firms are seen to outsource the skill intensive stages of production to Eastern Europe leading to an exodus of firms and high skill jobs to Eastern Europe. Are these fears justified?

To address these questions the paper makes use of new survey data of 660 German and Austrian firms with 2200 investment projects in transition countries during the period 1990 to 2001. The new survey data represent 100 percent of Austrian and 80 percent of German direct investment in Eastern Europe.

The paper is discussing three issues. First, I examine whether Eastern Europe has become a new member in the new international division of labor which has characterized the world economy in the last two decades. Is Eastern Europe becoming an important location for firms' international organization of production? (section 3) Then I examine whether an exodus of jobs to Eastern Europe has, in fact, taken place. Has Eastern Enlargement encouraged the relocation of firms to Eastern Europe substituting cheap Eastern workers for costly German or Austrian workers? (section 4) Third, I look at whether it is indeed the case that the high skill jobs are moving to the East as is repeatedly argued in the public press in Germany (section 5). Lastly I discuss some of the proposals made to address the problem of firms' outsourcing of high skilled labor. In particular I show that subsidizing R\&D activity in Germany or Austria to prevent the skill exodus to Eastern Europe will exacerbate the problem. I then suggest to immediately liberalize the movement of skilled workers with Eastern Enlargement to address the human capital crisis in Germany and Austria.

\section{Trade and Investment Integration with Eastern Europe}

Since the fall of communism trade integration with Eastern Europe has taken place on a fast pace in both countries. In 200111 percent of Germany's and 17 percent of Austria's exports are going to Eastern Europe and the CIS (Commonwealth of Independent States) and 13 percent of both countries imports are coming from this region. The trade shares with Eastern Europe have been in the range of 7 to 10 percent immediately after the fall of the iron curtain in 1990 in both countries (see Table 1). As a result Eastern Europe accounts now with 4.7 percent and 3.3 percent of GDP for more than 2/3 of all low wage imports in Austria and Germany, respectively (see Table 2). 
Table 1. Trade Integration with Eastern Europe

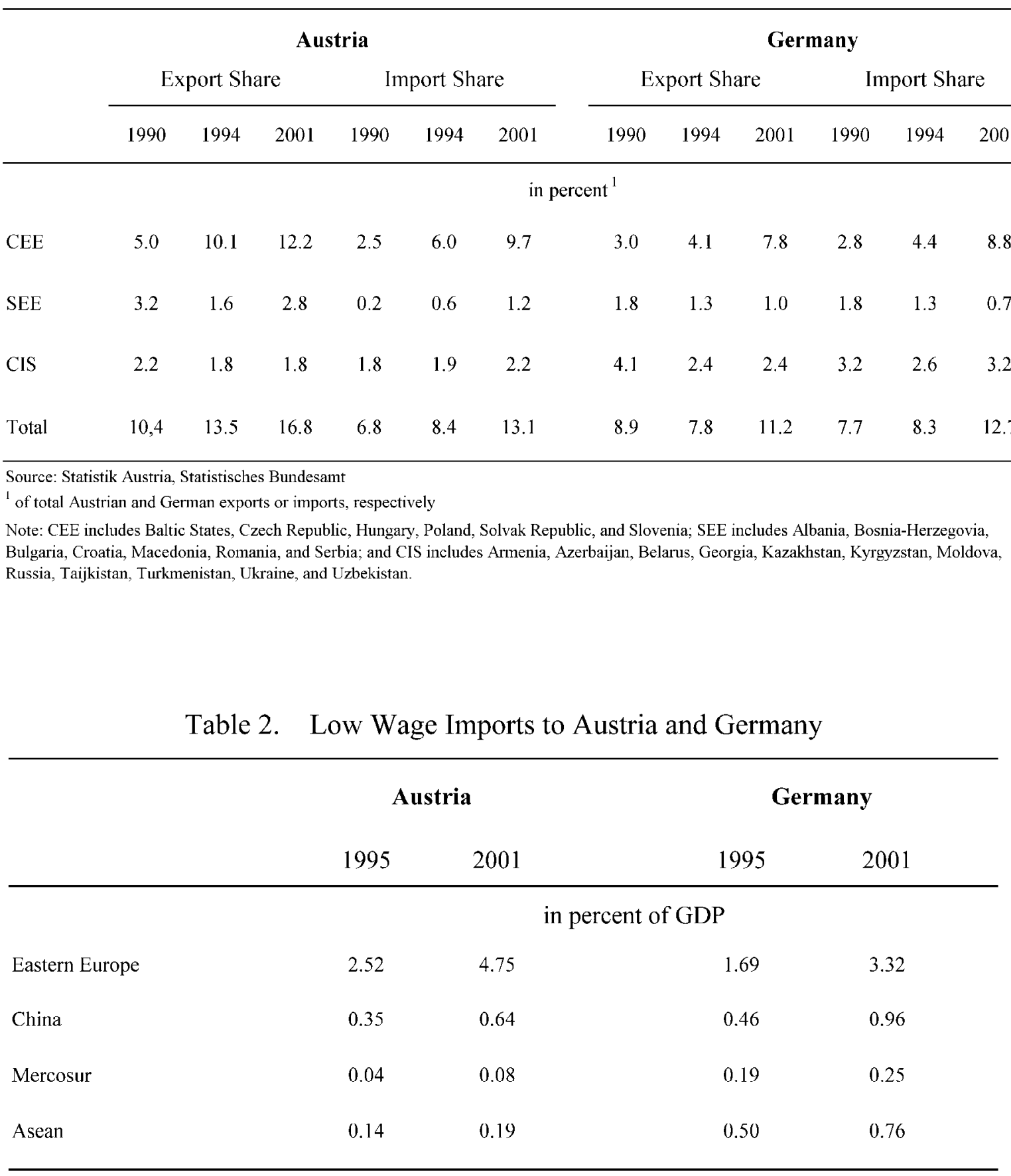

Source: EUROSTAT, Statistisches Bundesamt

Note: Eastern Europe includes Albania, Belarus, Bosnia and Herzegovina, Bulgaria, Estonia, Croatia, Hungary, Latvia, Lithuania, Macedonia, Moldova, Poland, Romania, Russia, Serbia, Slovakia, Slovenia, Czech Republic, and Ukraine; Mercosur includes Argentina, Bolivia, Brasilia, Paraguay, Uruguay; and Asean includes Brunei, Indonesia, Kambodscha, Laos, Myanmar, Philipines, Singapore, Thailand, and Vietnam. 
Table 3. Investment Integration with Eastern Europe

\begin{tabular}{|c|c|c|c|c|c|c|}
\hline & & Austria & & & German & \\
\hline & Outgol & $\mathrm{g} \mathrm{FDI}^{1}$ & Incoming $\mathrm{FDI}^{2}$ & Outgo & $\operatorname{lg~FDl}^{1}$ & Incoming $\mathrm{FDI}^{2}$ \\
\hline & $\begin{array}{r}\text { average } \\
1992-1994\end{array}$ & $\begin{array}{c}\text { average } \\
2000-2002\end{array}$ & $1998 / 99$ & $\begin{array}{c}\text { average } \\
1992-1994\end{array}$ & $\begin{array}{c}\text { average } \\
1999-2001\end{array}$ & $1998 / 99$ \\
\hline FDI to EE in percent of total FDI & 34.1 & 87.7 & - & 5.4 & 2.4 & - \\
\hline CEE & 94.8 & 81.0 & - & 90.7 & 83.6 & - \\
\hline Czech Republic & 29.0 & 16.7 & 11.5 & 32.8 & 18.1 & 29.6 \\
\hline Hungary & 52.9 & 23.1 & 11.7 & 36.9 & 12.5 & 28.0 \\
\hline Poland & 1.7 & 7.6 & 2.3 & 16.7 & 27.9 & 17.3 \\
\hline Siovak Repubiic & 5.2 & 24.3 & 16.9 & 3.4 & 22.9 & 22.0 \\
\hline Sluvenia & 5.8 & 9.1 & 37.5 & 0.3 & 0.9 & 12.0 \\
\hline Baltic States & 0.1 & 0.2 & 2.0 & 0.7 & 1.2 & 12.9 \\
\hline SEE & 4.1 & 12.2 & - & 3.1 & 16.0 & - \\
\hline Bulgaria & 0.6 & 1.1 & 7.2 & 3.2 & 1.2 & 8.0 \\
\hline Croatia & 2.9 & 8.0 & 19.3 & 1.0 & 12.0 & 27.9 \\
\hline Romania & 0.5 & 3.2 & 5.1 & 0.5 & 3.1 & 10.2 \\
\hline CIS & 0.5 & 6.2 & - & 4.0 & 7.4 & - \\
\hline Russia & 0.5 & 5.3 & & 2.7 & 7.0 & 8.1 \\
\hline Ukraine & 0.0 & 0.8 & 2.8 & 1.3 & 0.4 & 8.3 \\
\hline
\end{tabular}

Sourcc: Austrian National Bank, German National Bank, and UNCTAD (2000).

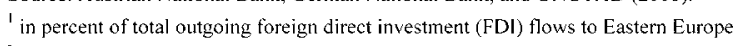

2 in percent of total inward foreign direct investment (FDI) stock in Fastern Furone

During the 1990s investment integration with Eastern Europe has been much more pronounced than trade integration, in particular in Austria. In 2001 Eastern Europe accounts for 88 percent of total outgoing investment in Austria, while the share of Eastern Europe in Germany's foreign investment is 4 percent only. Thus, with the opening up of Eastern Europe Austria has concentrated almost all its outgoing investment to this region, while on a global scale Eastern Europe is of little importance as a host region for Germany (see Table 3). Nevertheless, Germany and Austria are the most important investors in this region. Both countries account for around 50 percent of total incoming foreign investment in Croatia and Slovenia (see columns incoming FDI in Table 3 ) and for around 40 percent of total incoming investment in the Czech Republic, Hungary, and the Slovak Republic. German investment moves predominantly to the Czech Republic, Poland, Hungary, and Russia, while Austria's investment goes to Hungary, Slovakia, the Czech Republic, Slovenia and Croatia. Since the mid 1990s there has been a relocation of foreign investment from the accession countries to the candidate countries of the second round (in particular to Croatia) and to the CIS in particular in Germany. 


\section{The Data}

The firm survey among German and Austrian investors in Eastern Europe has been conducted in the years 1997-2001 in Germany and 1999-2001 in Austria. The sample consists of 2200 investment projects by 660 Austrian and German firms during the period 1990 to 2001. In terms of value the 1200 German investment projects represent 80 percent of total German investment in Eastern Europe, while the 1000 Austrian investment projects represent 100 percent of total Austrian investment in Eastern Europe. The data cover the period of 1990-2001, but the actual numbers are from the years 1997-2000 in Germany and 1999-200 in Austria.

Under communism practically no foreign direct investments in Eastern Europe have taken place due to a political ownership constraint. Thus, when we started the firm survey among German and Austrian firms with investments in Eastern Europe, we were in the unique situation to go for detailed information on each foreign investment project in Eastern Europe and at the same time to aim for a full population sample. The result is a data set that allows us to say something representative about how foreign direct investment and outsourcing to Eastern Europe affect the Austrian and German economy. At the same time, the data also allow us to say something representative of how incoming foreign investment is affecting Eastern Europe, because Austria and Germany are such important investors in this region (the two countries account for 40 to 50 percent of all incoming investment in many countries of Eastern Europe, see Table 3).

The questionnaire of the survey comes in three parts: information on parent firms in Austria and Germany, information on the actual investment project, and information on Eastern European affiliates and their environment. A parent firm may undertake more than one investment in Eastern Europe. In the sample the Austrian investor has undertaken 4 to 5 investments and the German investor 2 to 3 investments in Eastern Europe on average. Due to the length of the questionnaire (we collected information on about 500 variables) we personally visited the parent firms in Austria and Germany, respectively or conducted the interview by phone. Very few questionnaires have been sent out by mail and have been filled out anonymously. The sample is unique in several dimensions. First, it includes detailed information on parent firms in Austria and Germany, like balance sheet data, the internal organization of the multinational enterprise, its global network, the incentive system used for its workers, power relations between parent and affiliates etc. Second, it contains information about how and where the investment is financed. Third, it includes information on affiliates in Eastern Europe like ownership structure, type of ownership, financial structure, competitive environment, parent and affiliate trade relations etc. The sample consists of quantitative as well as qualitative information.

\section{A New Member in the Global Division of Labor?}

Is Eastern Enlargement offering Eastern Europe the prospect of becoming a new member in the new international division of labor? If yes, what kind of firm activity is transferred to 
Eastern Europe? In the last two decades the world economy has gone through a dramatic change. A new international division of labor is emerging in the world economy. The global firm produces one input in one location which is then send for refinement to a second location. The refined input then gets further refinement in a third location. Thus, firms geographically separate different production stages across the world economy to exploit differences in production costs. ${ }^{2}$ Take the example of the German firm Siemens. As other global corporations, Siemens has organized its activities in a global value chain with its R\&D and engineering activity located in Europe and the US, procurement and logistics located in South East Asia, its assembly activity located in Eastern Europe, and its marketing activity organized on the local market or via the internet. ${ }^{3}$ Is this organizational pattern a more general trend among firms in Austria and Germany, respectively and is Eastern Europe becoming an important location for these firms in their global organization of production?

In other words, why do German and Austrian firms invest in Eastern Europe (EE)? Do they want to replicate their production facilities in the countries in EE or do they want to exploit differences in factor costs between Germany and Austria on the one hand and EE on the other? The former is a horizontal foreign direct investment (FDI) and is primarily motivated to gain access to the host country market. The latter is a vertical FDI and is motivated by wage differentials. ${ }^{4}$ One reason why we might be interested to distinguish between these two forms of multinational activity is to identify their potential effects on wage inequality and employment levels in Austria and Germany.

If an outward investment to Eastern Europe is just an expression of German or Austrian firms taking control over assets in Eastern Europe without a cross-border shift in production capacity, then foreign investments in Eastern Europe will have little effect on wages and employment levels in Germany or Austria. If an outward investment actually involves a shift in production capacity, then the issue is whether the outgoing investment is vertical or horizontal in nature. In a vertical FDI European firms outsource the labor intensive part of their production to a low wage country in Eastern Europe and cut this production stage in the skill labor abundant European Union. Thus, a vertical foreign investment leads to an increase in the wage of skilled relative to unskilled labor or to an increase in unemployment of unskilled labor in the European Union when wages are not allowed to adjust. In a horizontal FDI the European firms produce the same products in their affiliates in Eastern Europe. Horizontal FDI is driven by market access considerations, while vertical FDI is motivated by differences in factor prices between the European Union and the countries in Eastern Europe. Thus, FDI is more likely to generate wage inequality or unemployment in the European Union when it is vertical in nature.

\footnotetext{
${ }^{2}$ The new features of globalization are described in the Globalization Report to the European Commission, see Bourguignon et al 2002.

${ }^{3}$ See Financial Times Deutschland, 12. December 2003, and Sorg, Armin, Erwartungen und Erfahrungen eines Großunternehmens: Das Beispiel der Siemens AG, Ökonomische Konsequenzen einer EU-Osterweiterung, Friedrich Ebert Stiftung, Digitale Bibliothek, Bonn 2001.

${ }^{4}$ For the theory of vertical FDI, see Helpman (1984), Helpman and Krugman (1985), for theories of horizontal FDI, see Brainard (1993, 1997), Markusen and Venables (2000).
} 
Figure 1. Comparative Advantage with Eastern Europe

\section{Germany}

country
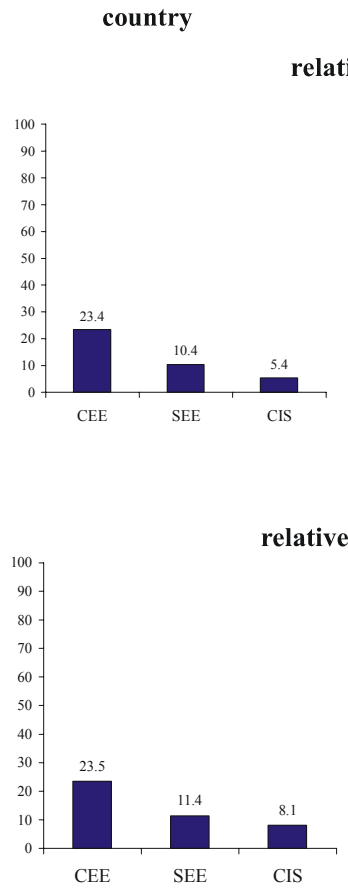

relative productivity ${ }^{2)}$

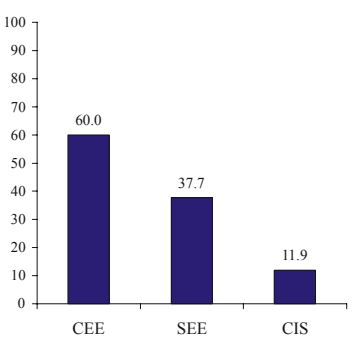

relative unit labor costs ${ }^{3)}$
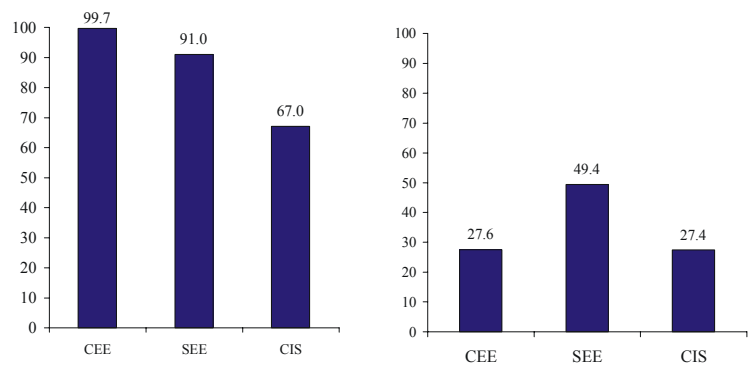

\section{Austria}

country relative wage $^{1)}$
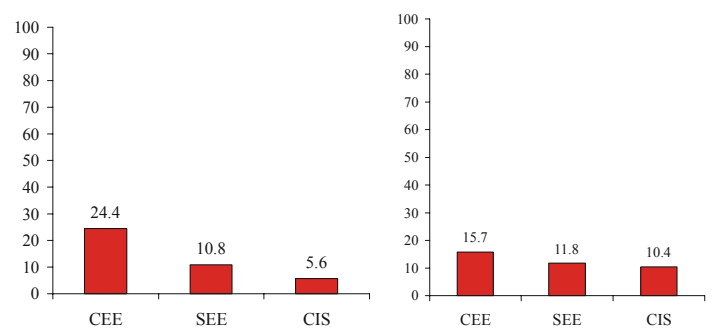

relative productivity ${ }^{2)}$

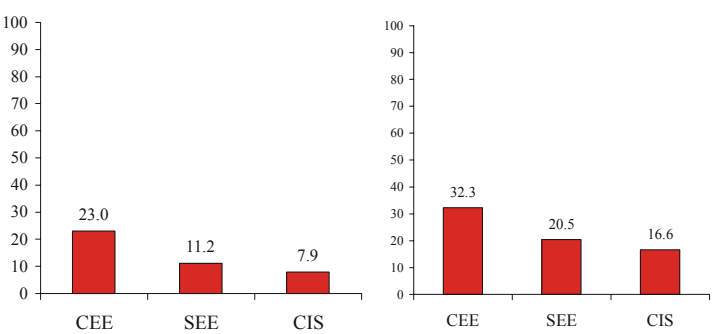

relative unit labor costs ${ }^{3)}$
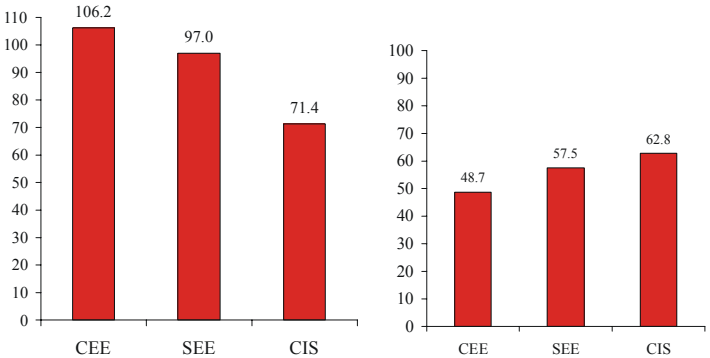

Source: The Vienna Institute for International Economic Studies (wiiw); Statistisches Bundesamt; Statistik Austria; Chair of In ternational Economics, University of Munich, firm survey of 2200 investment projects in Eastern Europe by 660 firms

${ }^{1)}$ country: average wage (wage bill per employee) in Eastern Europe relative to Germany and Austria, respectively, in 200

firm: average wage (wage bill per employee) of affiliates in Eastern Europe relative to parent firms in Germany and Austria, respectively; for Austria in 1999-2000 and for Germany in 1997-2000

${ }^{2)}$ country: GDP per employment in Eastern Europe relative to Germany and Austria, respectively, in 2001

firm: sales per employee of affiliates in Eastern Europe relative to parent firms in Germany and Austria, respectively; for Austria in 1999-2000, and for Germany in 1997-2000

${ }^{3)}$ country: wage bill divided by GDP in Eastern Europe relative to Germany and Austria, respectively, in 2001

firm: wage bill divided by sales of affiliates in Eastern Europe relative to parent firms in Germany and Austria, respectively; for Austria in 1999-2000; for Germany in $1997-2000$ 
When multinational firms wish to exploit differences in factor costs in Eastern Europe how much in terms of labor costs can they save when establishing an affiliate in Eastern Europe? In Figure 1 we compare relative wages, relative productivity, and relative unit labor costs between Austria and Germany on the one hand and the accession countries (CEE), the candidate countries of the second round (SEE), and the countries of the former Soviet Union (CIS) on the other. We focus first on Germany. It appears from the left panel of Figure 1 that wages in the accession countries are about 23 percent of those in Germany, while these countries' productivity has reached about 23 percent of Germany's productivity level. As a result, labor unit costs in the accession countries are the same as in Germany. Thus, when German firms buy input goods in one of the accession countries they do not save on costs for the input good compared to when the input is produced in Germany.

Can these costs be reduced when multinational firms open an affiliate in one of the accession countries and produce the input themselves? Figure 1 reveals that German affiliates in the accession countries pay 17 percent of their German parent wages but are increasing their productivity to 60 percent of the parents' productivity level. Therefore, they can reduce the labor costs by 72 percent relative to their parent firms' cost in Germany.

In the SEE countries (Romania, Bulgaria, Croatia) both wages and productivity are low so that unit labor costs in the SEE countries are 91 percent of Germany's unit labor costs. Furthermore, these costs are not reduced by as much as in the CEE countries when German firms produce locally in the SEE countries (labor cost are reduced by 50 percent), since producing locally does not help to increase productivity as much as in the CEE countries.

The picture looks different in the CIS countries. Relative wages in Russia and Ukraine are 5 percent of Germany's, while these countries have 8 percent of Germany's productivity, so that their unit labor costs are 67 percent of Germany's. However, when German firms produce locally in affiliates in the CIS they can save 73 percent of their labor costs due to lower wages of German affiliates in Russia and Ukraine.

From these numbers it appears that the accession countries are a particular attractive location for German investors due to the relatively high productivity levels of their affiliates in these countries. The CIS are also attractive locations due to their low relative wages in particular in German affiliates in these countries. The SEE countries, however, do not appear to bring as much in terms of labor cost savings.

The right panel of Figure 1 gives the same data for Austria. At the country level Austria's comparative advantage with Eastern Europe looks very similar to that of Germany. The numbers suggest that relative to Austria the CIS countries have the lowest labor unit costs followed by the SEE, while the CEE countries have already stopped to have lower production costs than Austria. However, the ranking of regions is reversed at the firm level. When Austrian multinationals produce locally, they can save 51 percent of their labor costs in their accession countries' affiliates, 42 percent in their SEE' affiliates, and only 37 percent of the costs in their CIS' affiliates. 
But how important are each of these motivations - market seeking versus cost advantage seeking - for foreign direct investments in Eastern Europe? Are German and Austrian firms primarily moving their activities to Eastern Europe to exploit differences in factor prices or do they want to be close to the Eastern European market by producing locally?

One way to answer this question is to look at the pattern of intra-firm trade. In Table 4 I use the pattern of intra-firm trade as a criterion whether German and Austrian foreign investments in Eastern Europe, respectively are market seeking or cost advantage seeking. I define a foreign investment in Eastern Europe as a multinational outsourcing activity driven to exploit differences in factor prices when parent firms in Austria and Germany, respectively export input goods to their affiliates in Eastern Europe as well as import these goods back from their affiliates in Eastern Europe after refinement. Thus, in an outsourcing activity affiliates in Eastern Europe do not produce exclusively for the local market. This way, multinational outsourcing involves an intra-firm export from the parent firm in Germany or Austria to their affiliates in Eastern Europe as well as an intra-firm import from their affiliates in Eastern Europe to Germany or Austria. ${ }^{5}$

I focus first on Germany. From the right panel of Table 4 we see that on average 45 percent of all German investment to Eastern Europe fulfill these criteria and are outsourcing activities of German firms motivated by lower wages in Eastern Europe. The importance of outsourcing investment becomes, however, much larger for individual Eastern European countries. Outsourcing dominates among German investment in the Czech Republic, Bulgaria, Slovakia, and Romania (share of around 70 percent). It plays little role in Slovenia and Poland. When a tighter criterion for outsourcing is used requiring that parent firms import at least 20 percent of their Eastern European affiliates' output rather than import at all, German multinationals outsourcing is reduced to 10 percent in the Czech Republic, to 7 percent in Russia and to 2 percent in Ukraine. All the other numbers remain the same.

Among Austrian multinationals the outsourcing activities to Eastern Europe are much less important. Only 17 percent of total Austrian investment to Eastern Europe is motivated by lower wages in Eastern Europe. But again the share varies considerably across individual countries in Eastern Europe. 68 percent of Austria's investment in Russia and 42 percent of its investment in Poland are motivated by factor prices. These numbers are not changed when the stricter criterion for outsourcing is applied requiring parent firms to import at least 20 percent of their Eastern European affiliates' output.

\footnotetext{
${ }^{5}$ In the literature different definitions of outsourcing have been used. Hummels et al (2001) use input-output tables at the industry level to calculate an index of vertical specialization. Vertical specialization is defined as the share of imported inputs which is reexported. Hanson et al (2001) use the notion of export platforms to calculate the share of exports in percent of affiliates' output of US multinationals. The criterion for outsourcing used here is somewhat more strict than those in the literature. It is more strict than Hummels et al's measure of vertical specialization, since I include intra-firm inputs only, while Hummels et al include inputs also between independent firms. It is also more strict than Hanson et al's concept of export platforms, since I require an import as well as an export between parent and affiliates and I include exports of affiliates to parent firms only, while Hanson et all include all exports of affiliates whatever their destination in their measure of export platforms.
} 
Table 4. Multinationals' Outsourcing Activity to Eastern Europe ${ }^{\text {l) }}$

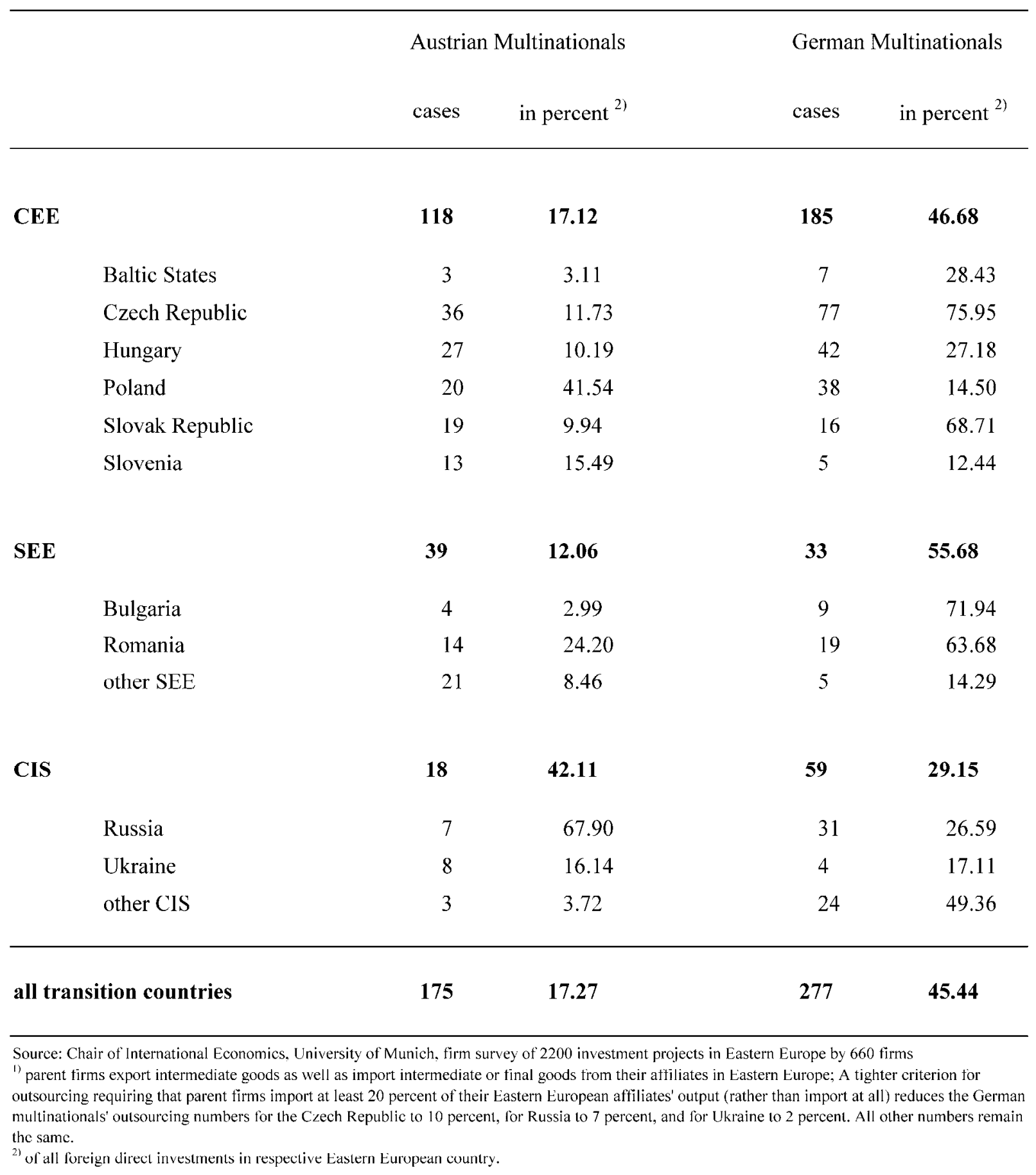


Table 5. Multinationals' Investments and Outsourcing to Eastern Europe by Sector

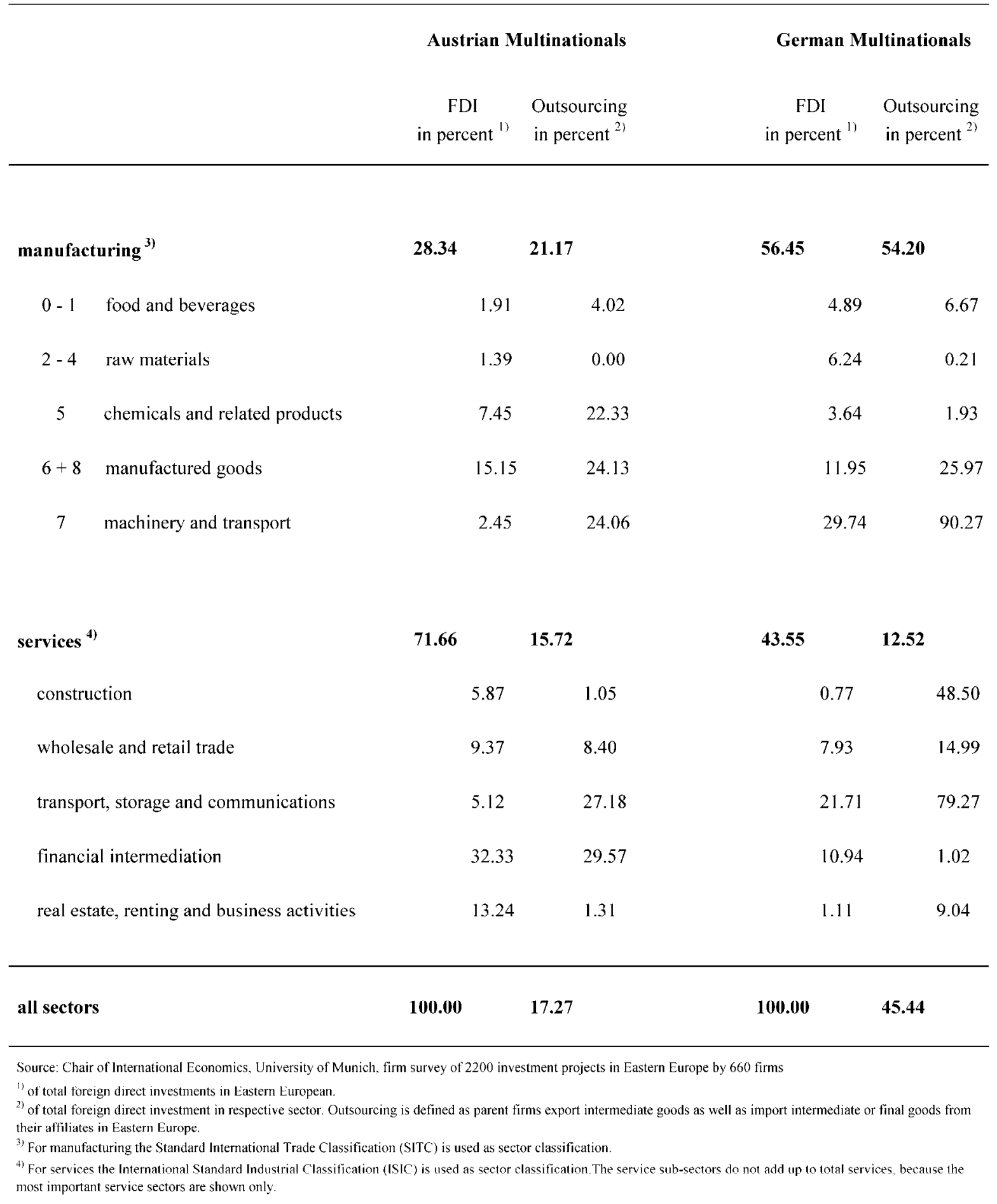


Next, we examine the pattern of multinational investment and outsourcing across sectors (Table 5). German investment is predominantly engaged in manufacturing activity in Eastern Europe (almost 60 percent of total investment), of which manufactured goods and machinery and transport are the most important sectors. Austrian investment is predominantly involved in services (more than 70 percent of total investment) in particular in banking and financial intermediation. This can be illustrated by the importance of one single multinational firm in each of these countries. Both Siemens, a manufacturing firm, and Bank Austria, a bank, each account for about 10 percent of Germany's and Austria's investment in Eastern Europe, respectively. Table 5 reports also the importance of outsourcing for individual sectors. It appears from the table that 90 percent of German investment in machinery and transport are outsourcing investments. Outsourcing plays also an important role in manufactured goods for both German as well as Austrian investment. More surprisingly however, outsourcing is not confined to manufacturing and has become a dominant phenomenon in services as well such as logistic services (transport, storage and communication) with 79 percent of outsourcing investment in Germany and 27 percent in Austria. Note also, that with 30 percent of investment, outsourcing has become prevalent in the banking and financial sector in Austria as well. ${ }^{6}$

Finally, we ask how important are firms' outsourcing activities to Eastern Europe for Germany's and Austria's international trade, respectively with these countries? In other words, what is the share of intra-firm trade - trade which takes place inside the multinational enterprise between parent firms and their affiliates in Eastern Europe - in foreign trade between Germany and Eastern Europe on the one hand and Austria and Eastern Europe on the other? The answer to this question is given in Table 6. I focus first on Germany. Although firms' outsourcing activity is a dominant feature of German investment in Eastern Europe, it is not very important for its trade with Eastern Europe. Only 12 percent of Germany's exports to Eastern Europe are intra-firm exports and 22 percent of its imports from Eastern Europe are intra-firm imports. But again there is considerable variation across individual countries. For example, Germany's trade with the Slovak Republic is dominated by intra-firm trade. 65 percent of Germany's imports from Slovakia and 34 percent of its exports to Slovakia are trade within the multinational enterprise between German parent firms and their affiliates in Slovakia.

In contrast, Austria's international trade with Eastern Europe is dominated by intra-firm trade, in spite of the fact that outsourcing is not an important motivation for Austria's investment in Eastern Europe. Almost 70 percent of Austria's imports from Eastern Europe are goods from Austria's affiliates in Eastern Europe to their parent firms in Austria. 22 percent of Austria's exports to Eastern Europe is trade within the multinational enterprise. The intra-firm trade ratios vary considerably across countries. For example, Hungary's intra-firm exports to Austria are exceeding those of the official trade statistics, while trade with Bulgaria is mainly trade outside the multinational corporation between two independent firms. It is interesting to note, that Austria's trade with Russia has a significant share of intra-firm trade. This is not surprising since outsourcing dominates among Austria's FDI in Russia.

\footnotetext{
${ }^{6}$ See also The Economist December 2003 who points to the recent importance of outsourcing activities in IT and other services.
} 
In sum, the pattern of vertical specialization that has emerged between Germany and Eastern Europe on the one hand and Austria and Eastern Europe on the other, suggests that some of the Eastern European countries like Hungary, Poland, the Slovak Republic, Romania, and Russia have clearly become new members in the international division of labor. 
Table 6. Intra-Firm Trade in Total Trade with Eastern Europe

\begin{tabular}{|c|c|c|c|c|}
\hline & \multicolumn{2}{|c|}{ Austria ${ }^{1)}$} & \multicolumn{2}{|c|}{ Germany $^{2)}$} \\
\hline & $\begin{array}{l}\text { share of intra-firm } \\
\text { exports in total } \\
\text { exports to Eastern } \\
\text { Europe }^{3)}\end{array}$ & $\begin{array}{l}\text { share of intra-firm } \\
\text { imports in total } \\
\text { imports from } \\
\text { Eastern Europe }\end{array}$ & $\begin{array}{l}\text { share of intra-firm } \\
\text { exports in total } \\
\text { exports to Eastern } \\
\text { Europe }^{3)}\end{array}$ & $\begin{array}{l}\text { share of intra-firm } \\
\text { imports in total } \\
\text { imports from } \\
\text { Eastern Europe }\end{array}$ \\
\hline & \multicolumn{4}{|c|}{ in percent } \\
\hline \multicolumn{5}{|l|}{ CEE } \\
\hline Baltic states & 13.95 & n.a. & 5.19 & 14.41 \\
\hline Czcch Republic & 19.67 & 42.17 & 6.83 & 15.64 \\
\hline Hungary & 20.03 & $136,47^{5)}$ & 11.95 & 40.46 \\
\hline Poland & 41.08 & 64.91 & 17.77 & 15.34 \\
\hline Slovak Republic & 26.11 & 54.71 & 34.01 & 64.98 \\
\hline Slovenia & 18.70 & 48.36 & - & - \\
\hline \multicolumn{5}{|l|}{ SEE } \\
\hline Bulgaria & 3.36 & 11.32 & - & - \\
\hline Croatia & 16.08 & 40.40 & - & - \\
\hline Romania & 22.72 & 57.46 & 3.86 & 7.17 \\
\hline \multicolumn{5}{|l|}{ CIS } \\
\hline Russia & 34.57 & 26.70 & 4.94 & 1.67 \\
\hline Ukraine & 12.00 & 21.52 & 4.51 & 2.44 \\
\hline total & 22.40 & 68.52 & 11.67 & 21.56 \\
\hline \multicolumn{5}{|c|}{$\begin{array}{l}\text { Source: Chair of International Economics, University of Munich, firm survey of } 2200 \text { investment projects in Eastern Europe by } 660 \text { firms, Statistik Austria, Statistisches } \\
\text { Bundesamt }\end{array}$} \\
\hline \multicolumn{5}{|c|}{$\begin{array}{l}\text { 1) For Austria total trade with Eastern Europe is the average of } 1999-2000 \text {, since the numbers of intrafirm exports and imports from the firm survey are from these years. } \\
\text { The survey information on intrafirm exports and imports varied greatly for individual countries in Eastern Europe due to missing cases. In order to make the intrafirm trad } \\
\text { numbers comparable with total trade with Eastern Europe, we artificially reduced total exports and imports by the number of missing cases of intra-firm exports and } \\
\text { imports for individual Eastern European countries. Exports and imports from Eastern Europe, respectively, are reduced by a factor of }(0.17,0.10) \text { for the Czech Republic, } \\
\text { by }(0.51,0.39) \text { for Hungary, by }(0.26,0.24) \text { for Poland, by }(0.58,0.30) \text { for the Slovak Republic, by }(0.55,0.20) \text { for Slovenia, by }(0.48,0.47) \text { for Bulgaria, by }(0.38,0.11) \\
\text { for Croatia, by }(0.62,0.47) \text { for Romania, and by }(0.74,0.62) \text { for Russia. For the Baltic States and for Ukraine total trade is not reduced because of no missing cases. } \\
{ }^{2)} \text { For Germany total trade with Eastern Europe is the average of } 1996-2000 \text {, since the numbers of intrafirm exports and imports from the firm survey are from these } \\
\text { years. The survey information on intrafirm exports and imports varied greatly for individual countries in Eastern Europe due to missing cases. In order to make the } \\
\text { intrafirm trade numbers comparable with total trade with Eastern Europe, we artificially reduced total exports and imports by the number of missing cases of intra-firm } \\
\text { exports and imports for individual Eastern European countries. Exports and imports from Eastern Europe, respectively, are reduced by a factor of }(0.63,0.50) \text { for the } \\
\text { Baltic States, by }(0.13,0.00) \text { for the Czech Republic, by }(0.60,0.40) \text { for Hungary, by }(0.87,0.52) \text { for Poland, by }(0.10,0.00) \text { for the Slovak Republic, by }(0.57,0.35) \text { for } \\
\text { Romania, by }(0.64,0.34) \text { for Russia, and by ( } 0.75,0.00) \text { for Ukraine. For Slovenia, Bulgaria, and Croatia total trade is not reduced because of no missing cases. } \\
\text { 3) intermediate inputs delivered by parent firms to Eastern European affiliates } \\
\text { 4) intermediate or final goods delivered by Eastern European affiliates to parent firms for marketing or further reprocessing }\end{array}$} \\
\hline
\end{tabular}




\section{An Exodus of Jobs?}

In the previous section we have documented that German and Austrian firms can save a substantial amount of labor costs (between 37 to 73 percent) by outsourcing activities to Eastern Europe. We also showed that in Germany 45 percent and in Austria 17 percent of investments in Eastern Europe are motivated by lower wages in Eastern Europe in which these firms outsource labor intensive production stages to Eastern Europe. Does this imply that these outsourcing activities have caused major job losses in Germany and Austria, respectively? We first look at what firms themselves say they are doing and then turn to an econometric analysis.

\subsection{What the Firms say}

In this section we give a back on the envelope calculation of multinational job relocations to Eastern Europe based on what multinational corporations say they are doing. In the firm survey we ask firms to classify what motivated their investment to Eastern Europe and whether or not the investment is a relocation of production to Eastern Europe or created additional capacity in Eastern Europe beyond the production in Austria and Germany, respectively. The motivations considered are access to the Eastern European market, market size, lower production costs, availability of well trained skilled labor, avoidance of transport costs and of exchange rate risk etc. In addition firms gave us information on how many jobs each of their investment created in Eastern Europe. A positive response to lower production costs and to offshore production in the survey together with the filled in information on jobs in Eastern Europe is then used to compute the job losses associated with offshore production in Austria and Germany, respectively. 


\section{Table 7. Multinationals' Job Relocations to Eastern Europe}

\begin{tabular}{|c|c|c|}
\hline & Austria & Germany \\
\hline & \multicolumn{2}{|c|}{ number of jobs } \\
\hline \multicolumn{3}{|l|}{ Relocation Induced Jobs } \\
\hline \multicolumn{3}{|l|}{ due to: } \\
\hline offshore production & $-10,494$ & $-115,698$ \\
\hline low production costs & $-38,022$ & $-117,074$ \\
\hline affiliate to parent productivity, in percent & 48.03 & 39.16 \\
\hline Job Destruction & $-24,221$ & $-91,158$ \\
\hline \multicolumn{3}{|l|}{ Trade induced Jobs } \\
\hline due to: & & \\
\hline induced exports to EE & 7,157 & 36,606 \\
\hline induced imports from $\mathrm{EE}$ & $-4,901$ & $-34,555$ \\
\hline Job Creation & 2,257 & 2,051 \\
\hline Net Job Destruction & $-21,964$ & $-89,106$ \\
\hline in percent of parent employment & -1.49 & -0.74 \\
\hline in percent of total employment & -0.71 & -0.26 \\
\hline Totai Affiiliates Empioyment & 201,795 & 463,550 \\
\hline Total Parent Employment & $1,473,176$ & $12,044,598$ \\
\hline Total Employment & $3,106,000$ & $34,133,000$ \\
\hline
\end{tabular}

Source: Chair of International Economics, University of Munich, firm survey of 2200 investment projects in Eastern Europe by 660 firms

Notes:

offshore production: number of jobs created in Eastern European affiliates, when firms classified the investment as a relocation activity from Germany and Austria, respectively.

low production costs: number of jobs created in Eastern European affiliates, when investors ranked low production costs as decesive or important motivation for the investment.

affiliate to parent productivity: ratio of sales per employee in Eastern European affiliates to sales per employee in parent firms. induced exports: number of jobs created in Austria and Germany, respectively, due to inputs delivered by parent firms to affiliates in EE. The value of inputs is divided by parent firms value added per worker to obtain the number of jobs created in Austria and Germany, respectively.

induced imports: number of jobs lost in Austria and Germany, respectively, due to intermediate and final goods sent by affiliates in Eastern Europe to parent firms. The value added of EE affiliates is divided by parent firms value added per worker to obtain the number of jobs lost in Austria and Germany, respectively. 
The calculation is given in Table 7. German multinationals have created 463.550 jobs and Austrian multinationals 201.795 jobs in Eastern Europe. According to our calculation these newly created jobs in Eastern Europe have led to a direct loss of 90.000 jobs in Germany and 22.000 jobs in Austria due to multinational relocations to Eastern Europe. These figures are obtained by computing the jobs created by German firms in Eastern Europe when investors have given low costs or outsourcing as the prime motivation for the investment. Out of this motivation German firms have created 232,772 jobs in Eastern Europe, which accounts for 50 percent of total German affiliates' employment in Eastern Europe. Note however, that German affiliates in Eastern Europe have on average 39 percent of the productivity level of their parent firms only. Therefore, one job created in Eastern Europe is equivalent to a 0.39 job lost in Germany implying a relocation induced job destruction of 91.158 jobs in Germany.

But the opening of a subsidiary in Eastern Europe creates new trading opportunities. German parent firms typically deliver inputs for further refinement to their affiliates in Eastern Europe. These intra firm exports to EE create 36.606 jobs in Germany. The number is obtained by computing the number of jobs created in Austria and Germany, respectively due to inputs delivered by parent firms to affiliates in Eastern Europe. To compute the number of jobs created in Germany we divide the value of inputs send to affiliates in Eastern Europe by the parents' value added per worker. Thus, 36.606 workers in Germany were used to produce the value of inputs send to Eastern European affiliates.

Eastern European affiliates, in turn, deliver the refined inputs or final goods back to parent companies. These intra firm imports from EE destroy 34.555 jobs in Germany. Again this number is obtained by computing the number of jobs destroyed in Germany due to EE affiliates' delivery of goods to parent firms in Germany. The value added of Eastern European affiliates is divided by parent firms' value added per worker. Thus, 34.555 workers are not used in German production, because the value added is produced by Eastern European affiliates. The described intra-firm exports and imports lead to a net trade induced job creation of 2.051 jobs. This adds up to a net destruction of 89.106 jobs in Germany.

An analogous computation results in a net destruction of 21.964 jobs in Austria. It is interesting to note that Austrian firms create 48.516 jobs in Eastern Europe out of a cost saving motivation, which accounts for 24 percent of total Austrian affiliates employment in Eastern Europe. This is half as much as in Germany where 50 percent of affiliates' jobs in Eastern Europe are created out of cost considerations. ${ }^{7}$ Taking the productivity differential between parent and affiliates and intra firm trade into account the job creation in Eastern Europe translates into a destruction of 21.964 jobs in Austria.

The computation in Table 7 is a rough calculation and has to be taken for what it is. Thus, the computed job numbers have to be interpreted with caution. In particular, the calculation has

\footnotetext{
${ }^{7}$ This is consistent with the findings of the previous section that outsourcing activities dominate among German investment, but not among Austrian investment in Eastern Europe. One reason for this difference between Germany and Austria is the different pattern of specialization of German and Austrian investment in Eastern Europe reported in Table 5. Germany is predominantly engaged in machinery and transport with 90 percent of outsourcing investment, while Austria is predominantly involved in banking with 30 percent of outsourcing investment.
} 
the following shortcomings. As the calculation is based on firms' perspectives, it assumes that one job lost at the level of the firm translates into one job lost to the economy as a whole. Thus, the computation ignores any general equilibrium effects. Typically, when workers loose their jobs at one particular firm, they are reemployed at some other firms with an accompanied adjustment in wages. Ignoring such general equilibrium effects may be justified when wages are not allowed to adjust due to labor market rigidities. Figure 2 of section 5 indeed shows that relative wages remained more or less fixed in both countries during the 1990s suggesting that these general equilibrium effects could not fully work themselves through the system. Thus, applying the 1 to 1 assumption does not seem to be completely unrealistic for Austria and Germany. In any case, the computation results in stronger job losses in Germany and Austria, respectively than would have taken place otherwise with flexible wages when general equilibrium effects are taken into account and thus can be seen to represent an upper bound of the true job losses due to outsourcing.

The computed losses of 89.106 jobs in Germany and of 21.964 jobs in Austria account for about 0.3 percent and 0.7 percent of total employment in Germany and Austria, respectively. These are indeed small numbers.

Why are these job losses so surprisingly low? To get to an answer we turn now to an econometric analysis of multinational's labor demand.

\subsection{An Econometric Analysis}

In this section I examine whether and how multinationals' labor demand across locations is related by estimating labor demand functions of German and Austrian parent firms. Does the multinational firm in Austria and Germany, respectively reduce labor demand in the Austrian and German labor market when wages in their affiliates in Eastern Europe decline? In this case cheaper labor in Eastern Europe substitutes for expensive labor in Austria and Germany.

Consider a firm producing in a number of countries. The firm that can decompose production across borders maximizes global profits. Global profits is the sum of revenues across locations of production minus production costs. The firm chooses a vertical decomposition of production to optimize over relative wages leading to complementarity in labor demands between locations. Thus, the location of production stages depends on relative wages if trade barriers are not prohibitive. Assembly is produced in the low wage location if there is intrafirm trade. In a simple two country case, the parent's labor demand $L_{i}$ can be expressed as

$$
L_{i}=\alpha_{i}+\beta_{i} w_{i}+\beta_{j} w_{j}+\gamma_{i} Y_{i}+\gamma_{j} Y_{j}
$$

The multinational's reduced form labor demand for a given affiliate location $\mathrm{j}$ is the weighted sum of labor costs $\mathrm{w}$ and demand conditions $Y$ across locations. ${ }^{8}$ The focus of our empirical

\footnotetext{
${ }^{8}$ For the model, see Riker and Brainard (1997).
} 
analysis is to estimate the cross-elasticity of labor demand $\beta_{j}$. If production is vertically decomposed then the parent's labor demand will be decreasing in the wage in its location, $\beta_{i}<0$, decreasing in the wage of its affiliate location $\beta_{j}<0$, increasing in local demand $\gamma_{j}>0$, and increasing in foreign demand $\gamma_{j}>0$. On the other hand, if production is not vertically decomposed, then $\beta_{j} \geq 0$. With $\beta_{j}<0$, multinationals are linked internationally at the firm level through trade in intermediate and final goods. As a result of those trade links affiliate jobs are complements rather than substitutes for parent firm jobs.

We estimate a log-linear version of the parent's labor demand equation (1) using ordinary least squares based on our firm survey data of 2200 investment projects in Eastern Europe by 660 firms in Austria and Germany. The data are at the firm level and are a cross section for the years $1997-2000$ in Germany and for the years $1999-2000$ in Austria covering the production activity of German and Austrian affiliates in all countries of Eastern Europe including the former Soviet Union. Equation 1 includes industry dummies to account for firm heterogeneity as well as time dummies for the years $1997-2000$ in Germany and for the years 1999 2000 in Austria to control for time fixed effects. ${ }^{9}$ Due to data problems we will not distinguish between workers by skill level, because we do not observe wages for skills at the firm level. Wages $\mathrm{w}$ are average Euro denominated compensations per employee and $Y$ are sales of parent firms in Austria and Germany and their affiliates in Eastern Europe. The independent variable parent employment $L_{i}$ is number of workers of parent firms in Austria and Germany, respectively.

We estimate the model of multinational labor demand separately for affiliates in CEE, SEE and the CIS and for the two dominant sectors German machinery and Austrian banking allowing the slope terms $\beta$ and $\gamma$ to vary across these regions and sectors.

\footnotetext{
${ }^{9}$ We are not too worried about the potential problem of endogeneity of the independent variables firm wages and firm output, since the time dimension of the data set is limited. The data cover the period 1990 to 2001, but the actual figures are for the years 1997 to 2000 for Germany and 1999 to 2000 for Austria. A possible problem of endogeneity may arise when wages in Eastern Europe affiliates increase and wages of parent firms decline due to firms relocation of production towards Eastern Europe.
} 


\section{Table 8. Parent Labour Demand Equation}

\begin{tabular}{|c|c|c|c|c|c|c|}
\hline & \multicolumn{3}{|c|}{ Austria } & \multicolumn{3}{|c|}{ Germany } \\
\hline & CEE & SEE & CIS & CEE & SEE & CIS \\
\hline \multicolumn{7}{|c|}{ dependent variable: log parent employment } \\
\hline log parent output & $\begin{array}{c}0.88 * \\
(31.08)\end{array}$ & $\begin{array}{c}0.95^{*} \\
(14.72)\end{array}$ & $\begin{array}{c}1.11^{*} \\
(11.12)\end{array}$ & $\begin{array}{c}0.96^{*} \\
(35.33)\end{array}$ & $\begin{array}{l}0.97^{*} \\
(7.48)\end{array}$ & $\begin{array}{c}1.09^{*} \\
(26.03)\end{array}$ \\
\hline log parent wage & $\begin{array}{c}-0.86^{*} \\
(7.80)\end{array}$ & $\begin{array}{c}-0.86^{*} \\
(2.72)\end{array}$ & $\begin{array}{c}-2.20^{*} \\
(4.91)\end{array}$ & $\begin{array}{c}-0.48^{*} \\
(7.21)\end{array}$ & $\begin{array}{c}-0.76^{*} \\
(2.23)\end{array}$ & $\begin{array}{l}-0.38 \\
(1.42)\end{array}$ \\
\hline $\log$ affiliate output & $\begin{array}{l}-0.04 \\
(1.46)\end{array}$ & $\begin{array}{l}-0.04 \\
(0.70)\end{array}$ & $\begin{array}{l}-0.12 \\
(1.45)\end{array}$ & $\begin{array}{c}-0.07^{*} \\
(2.17)\end{array}$ & $\begin{array}{l}-0.13 \\
(0.97)\end{array}$ & $\begin{array}{c}0.00 \\
(0.07)\end{array}$ \\
\hline log affiliate wage & $\begin{array}{c}-0.16^{*} \\
(2.77)\end{array}$ & $\begin{array}{l}-0.04 \\
(0.43)\end{array}$ & $\begin{array}{c}0.08 \\
(0.67)\end{array}$ & $\begin{array}{c}-0.16^{*} \\
(3.34)\end{array}$ & $\begin{array}{c}0.14 \\
(0.73)\end{array}$ & $\begin{array}{l}-0.12 \\
(1.83)\end{array}$ \\
\hline constant & $\begin{array}{c}1.51 \\
(1.14)\end{array}$ & $\begin{array}{l}-1.47 \\
(0.42)\end{array}$ & $\begin{array}{c}10.47^{*} \\
(2.31)\end{array}$ & $\begin{array}{c}-4.33^{*} \\
(4.90)\end{array}$ & $\begin{array}{l}-2.37 \\
(0.52)\end{array}$ & $\begin{array}{c}-9.21 * \\
(3.53)\end{array}$ \\
\hline corr. $R^{2}$ & 0.786 & 0.829 & 0.921 & 0.844 & 0.825 & 0.949 \\
\hline number of oberservations & 401 & 90 & 35 & 311 & 38 & 62 \\
\hline
\end{tabular}

Note: Estimates are for a cross section of parent firms and their affiliates in Central Eastern Europe (CEE), Southern Eastern Europe (SEE) and the former Soviet Union (CIS) of the years 1997-2000 in Germany and 1999-2000 in Austria. Estimation is based on equation (1) and are OLS estimates including industry fixed effects and time dummies for the years 1997-2000 for Germany and 1999-2000 for Austria.

$\mathrm{t}$-values are reported in parentheses.

* significant at the $5 \%$ percent level 
The results of estimating equation (1) are reported in Table 8. Table 8 gives Austrian and German parent companies' labor demand, respectively for the accession countries CEE, the candidate countries of the second round SEE, and the countries of the former Soviet Union CIS. The estimated employment demand functions show that a 10 percent decline in affiliate wages in CEE countries leads to a 1.6 percent increase rather than decline in the parent company's employment demand in both Austria and Germany, respectively. These estimates suggest that the outsourcing activity of German and Austrian firms to the accession countries has actually helped to create jobs in Austria and Germany, respectively. Outsourcing some of the firm's activities to their accession countries affiliates has helped Austrian and German firms to save between 65 to 80 percent of their labor costs (see Figure 1) helping these firms to stay competitive in an increasingly competitive environment. Rather than competing with each other as alternative suppliers of the same final goods, affiliates in the accession countries complement each other by supplying different components of the same final good.

The picture looks different for the SEE countries. In the SEE countries affiliates' wages appear not to play any role for the parent firms' labor demand in Austria and Germany, respectively. At first, this seems surprising given the relative low wages in these countries. A look at Figure 1 offers, however, an answer. German and Austrian affiliates in these countries are not able to increase the productivity level as much beyond the country as a whole when producing locally. Therefore, outsourcing to the CEE countries does not offer the prospect of lowering German and Austrian firms' overall production costs as much as in the CEE countries. As an outsourcing location the SEE countries appear to be less attractive.

The picture looks again different for the CIS countries. Austria's and Germany's multinationals appear to follow a diverse strategy in these markets. German multinationals use the CIS countries to lower their overall production costs. A decline in CIS affiliate wages increases the German parent's labor demand. The relationship is significant at the 10 percent level. Austrian multinationals, however, appear to substitute cheap labor in the CIS for expensive labor in Austria. However, the relationship is not significant at conventional levels.

Finally, I estimate equation (1) for the two dominant sectors German machinery and Austrian banking. We include regional and time dummies to control for regional differences and time fixed effects. The results are shown in Table 9. Not surprisingly, the pattern of cross wage elasticities does differ qualitatively between machinery as the dominant manufacturing sector in Germany and banking as the dominant service sector in Austria. German machinery appears to be vertically integrated across borders with labor in different countries serving as complements rather than substitutes as $\beta \mathrm{j}<0$. The relationship is significant at the 10 percent level. Austrian banking activities appear to be horizontal with labor in different countries as substitutes as $\beta \mathrm{j}>0$. However, the estimated cross wage elasticity for the Austrian banking sector is not significant at conventional levels. 
Table 9. The Two Dominant Sectors:

German Machinery and Austrian Banking

\begin{tabular}{lcc}
\hline & Machinery & Banking \\
\hline dependent variable: log parent employment & & $1.03^{*}$ \\
log parent output & $1.03^{*}$ & $(18.63)$ \\
& $(31.83)$ & $-1.80^{*}$ \\
log parent wage & -0.09 & $(7.14)$ \\
& $(1.67)$ & $-0.14^{*}$ \\
$\log$ affiliate output & -0.06 & $(2.3)$ \\
& $(1.46)$ & 0.13 \\
$\log$ arfiliate waye & -0.09 & $(0.89)$ \\
& $(1.48)$ & $7.88^{*}$ \\
constant & $-10.56^{*}$ & $(2.88)$ \\
\hline corr. $R^{2}$ & $(12.24)$ & 0.828 \\
number of oberservations & 0.968 & 109 \\
\hline
\end{tabular}

Note: Estimates are for a cross section of parent firms and their affiliates in Eastern Europe for the years 1997-2000 in Germany and 1999-2000 in Austria. Estimation is based on equation (1) and are ULS estimates including regional fixed effects and time dummies for the years 1997-2000 tor Germany and 1999-2000 for Austria.

t-values are reported in parentheses.

* significant at the $5 \%$ percent level

In sum, job losses of Austrian and German investment in Eastern Europe appear low because of two reasons. First, in Austria horizontal investment driven by market seeking considerations dominate among investment in Eastern Europe. Second, among vertical investment driven by differences in factor prices affiliate jobs in Eastern Europe appear not to compete with jobs in Austria and Germany. German and Austrian firms increase their production and employment demand in Germany and Austria when workers in their affiliates in the accession countries become less costly. Lower costs of Eastern European affiliates help firms to lower overall productions costs and to stay competitive. This appears to be the reason why the job losses of Austrian and German investment in Eastern Europe are so strikingly low. ${ }^{10}$

\footnotetext{
${ }^{10}$ Riker and Brainard (1997), Brainard and Riker (1997) get very similar results for US multinational firms' investment strategy in face of NAFTA; see also Braconnier and Eckholm (2000) for Swedisch multinationals in Eastern Europe.
} 


\section{A Human Capital Crisis?}

In recent months a new concern has been raised by economic experts in Germany. German firms are now outsourcing headquarter activities to Eastern Europe. Germany is now loosing the good jobs, the high skilled, R\&D and IT jobs, not just the bad, low skilled jobs. Siemens, for example, announced in an interview with Financial Times Germany that it plans to outsource $1 / 3$ of its R\&D activity to subsidiaries located in low wage countries like India, China, or Russia. It also plans to centralize and outsource some of its headquarter activities like accounting and personnel management to Siemens subsidiaries in the Czech Republic. Siemens praised the high quality of skilled workers in Eastern Europe. Armin Sorg, the Chief Economist of Siemens argued at a conference on the Economic Consequences of Eastern Enlargement of the Friedrich Ebert Stiftung, that Eastern Europe is a particularly attractive location for Siemens compared to India and China, because of its proximity to Germany and because of the same culture and time zone. ${ }^{11}$ Similarly, Bank Austria has started to outsource mathematical software development and other headquarter activities to Russia. Are these corporate inversions of firm activities taking place at Siemens and Bank Austria only or are they a more general trend among multinational firms in Germany and Austria? ${ }^{12}$

\footnotetext{
${ }^{11}$ See Financial Times Deutschland, 12. December 2003, and Sorg, Armin, Erwartungen und Erfahrungen eines Großunternehmens: Das Beispiel der Siemens AG, Ökonomische Konsequenzen einer EU-Osterweiterung, Friedrich Ebert Stiftung, Digitale Bibliothek, Bonn 2001.

${ }^{12}$ The trend of corporate inversions has been observed in the US as well where US firms outsource IT jobs and other headquarter activity to India and partly China, see The Economist, January 2004.
} 


\section{Table 10. High Skill Jobs of German Affiliates in Eastern Europe}

\section{University and College Graduates}

(1)

(2)
Affiliates' High Skill Affiliate to Parent Skill Personnel Ratio
Ratio $^{2)}$

\section{R\&D Personnel}

(1)

(2)

Affiliates' R\&D Affiliate to Parent R\&D Personnel Ratio ${ }^{3)} \quad$ Personnel Ratio ${ }^{4)}$

\begin{tabular}{|c|c|c|c|c|}
\hline CEE & 49.94 & 2.93 & 11.10 & 0.85 \\
\hline Baltic states & 22.22 & 1.44 & 5.24 & 0.48 \\
\hline Czech Republic & 86.08 & 5.51 & 17.88 & 1.66 \\
\hline Hungary & 13.43 & 0.71 & 9.85 & 0.65 \\
\hline Poland & 26.45 & 1.45 & 6.48 & 0.48 \\
\hline Slovak Republic & 39.83 & 2.54 & 3.97 & 0.40 \\
\hline Slovenia & 8.33 & 1.10 & 17.07 & 1.06 \\
\hline SEE & 19.66 & 2.05 & 10.10 & 0.65 \\
\hline Bulgaria & 12.50 & 11.78 & 8.53 & 0.76 \\
\hline Croatia & 40.00 & 2.59 & 28.50 & 1.78 \\
\hline Romania & 12.77 & 1.31 & 6.91 & 0.33 \\
\hline CIS & 62.39 & 2.89 & 25.02 & 1.86 \\
\hline Russia & 62.58 & 2.86 & 27.82 & 2.88 \\
\hline Ukraine & - & - & 5.17 & 1.36 \\
\hline Total & 50.23 & 2.86 & 15.28 & 1.12 \\
\hline German parent firms & 17.57 & & 13.59 & \\
\hline
\end{tabular}

Source: Chair of International Economics, University of Munich, firm survey of 2200 investment projects in Eastern Europe by 660 firms

1) Number of empioyees with university and coilege degree in percent of ârîiliates' empioyment. The high skiil personnei ratios have been computed by adding up ail university and college graduates in affiliates in a particular Eastern European country divided by total affiliates' employment in that particular Eastern European country.

2) Affiliates' high skill personnel ratio relative to parents' high skill personnel ratio. The parent high skill personnel ratios have been computed by adding up all employees with university and college degrees in German parent firms divided by total parent employment in Germany. The affiliate to parent skill ratios in colum (2) are computed relative to the parent high skill personnel ratios of those German parent firms only that have invested in the particular Eastern European country under consideration. Therefore, the high skill personnel ratio of 86.08 of the Czech Republic, for example, divided by the high skill personnel ratio of all German parent firms of 17.57 does not result in 5.51 .

${ }^{3)}$ Number of employees engaged in R\&D or engineering in percent of affiliates' employment. The R\&D personnel ratios have been computed by adding up all employees engaged in R\&D or engineering in affiliates in a particular Eastern European country divided by total affiliates' employment in that particular Eastern European country.

${ }^{4)}$ Affiliates' R\&D personnel ratio relative to parents' R\&D personnel ratio. The parent R\&D personnel ratios have been computed by adding up all employees engaged in $R \& D$ or engineering in German parent firms divided by total parent employment in Germany. The affiliate to parent $R \& D$ ratios in column (2) are computed relative to the parent R\&D personnel ratios of those German parent firms only that have invested in the particular Eastern European country. Therefore, the R\&D personnel ratio of 17.88 of the Czech Republic, for example, divided by the R\&D personnel ratio of all German parent firms of 13.59 does not result in 1.66 . 
We can answer this question by looking at the number of skilled jobs German and Austrian firms are creating in their affiliates in Eastern Europe. How skill intensive is the activity undertaken by German and Austrian affiliates in Eastern Europe compared to their parent activity in Germany and Austria? Table 10 gives the relevant numbers for Germany.

I use two indicators to measure the skill intensity of German affiliates in Eastern Europe: the share of workers with a university or college degree and the share of personnel engaged in $R \& D$ or engineering activities in the manufacturing and service sector. The data suggest that the high skill ratios of affiliates (the number of university or college workers in percent of total affiliate workers) are 2 to 3 times as large as that of German parent firms in all three regions CEE, SEE, and CIS. The share of university or college graduates among affiliate workers in Eastern Europe varies between 86 percent (Czech Republic) and 8 percent (Slovenia). The most skill intensive activity is undertaken by affiliates in the Czech Republic (skill share of 86 percent), in Russia (skill share of 63 percent), in Croatia and Slovakia (skill share of 40 percent). This compares with an average share of university or college graduates of German parent firms of 18 percent only. Thus, measured by the number of university and college graduates, German affiliates in Bulgaria are 12 times as skill intensive than their German parent firms, affiliates in the Czech Republic 5.5 times as skill intensive, affiliates in Russia 2.9 times as skill intensive. Only affiliates in Hungary have a skill share below that of German parent firms.

A similar picture emerges when the skill intensity of German affiliates is measured by the share of workers engaged in R\&D and engineering (right panel of Table 10). The R\&D personnel ratios of affiliates in Eastern Europe range between 4.0 percent (Slovakia) and 27.8 percent (Croatia and Russia). This compares with an average R\&D personnel share of 13.6 percent of German parent firms. Thus, German affiliates in Russia are 2.9 times as R\&D intensive as their German parent firms, affiliates in the Czech Republic and Croatia 1.7 times as R\&D intensive, and affiliates in Ukraine 1.4 as research intensive. The remaining countries affiliates' R\&D intensity is below that of German parent firms.

In Table 11 I look at Austria's export of high skill jobs to Eastern Europe. It appears from the Table that the share of university and college graduate workers in percent of Austrian affiliates' workers in Eastern Europe range between 9.6 percent (Romania) and 34.8 percent (Russia) compared to a skill share of 14.7 percent of Austrian parent firms. Thus, only affiliates in Slovenia have a smaller employment share of university and college graduates compared to Austrian parent firms. Affiliates in Bulgaria employ 26 times as many university graduates compared to the Austrian parent company, affiliates in Ukraine 19 times, affiliates in Russia and Romania 3.7 times as many university graduates compared to Austrian parent firms. Although the R\&D ratios of Austrian affiliates are extremely high and much larger than that of German affiliates in Eastern Europe (they range between 3.8 percent in affiliates in the Baltic States to 45.8 percent in affiliates in Russia given in the right panel of Table 11), none of the Austrian affiliates' research and engineering activities in Eastern Europe exceed that of their Austrian parent firms with the exception of those in Russia. The reason for this is the extremely high R\&D intensity of parent firms in Austria. The high R\&D intensity of parent 
firms in Austria appear large indeed since they exceed that of German parent firms. This is quite striking.

One possible reason for this result is economic policy. The Austrian government gives strong tax incentives and subsidies to R\&D activity which might have made firms to move more into this activity in Austria and to locate less of this activity in Eastern Europe. ${ }^{13}$ One indication that the large R\&D ratios of parent firms in Austria are induced by policy is the diverse pattern between the skill personnel ratios and the R\&D ratios of Austrian affiliates in Eastern Europe. Typically, when the government subsidizes R\&D, the R\&D sector expands and competes with other sectors for skilled workers. However, when firms have the option to outsource some of the activities to Eastern Europe which use skilled workers but which do not qualify for a domestic R\&D subsidy (such as high tech activity in other sectors), they can avoid competing for talent in the local labor market. ${ }^{14}$

Take the example of Russia, Ukraine, and Bulgaria as outsourcing locations. Austrian affiliates in Bulgaria and Ukraine employ 26 to 19 times as many skilled workers in production than their parent firms in Austria, but only 0.27 and 0.14 times as many skilled workers in research and engineering. Similarly, but less striking in Russia. Austrian affiliates in Russia use 3.7 times as many skilled workers in production and the same amount of skilled workers in R\&D activity as Austrian parent firms. German affiliates in Russia use about the same skill intensity in production as well as research (see Tables 8 and 9). In sum, affiliate activities of Austrian multinationals in Eastern Europe appear to be more skill intensive in terms of their share of university and college workers but less skill intensive in terms of their R\&D intensity, although the R\&D ratios of Austrian affiliates in some of the Eastern European countries turn out to be extremely large.

\footnotetext{
${ }^{13}$ Moreover, Austria has one of highest share of state financed R\&D, see Marin (1995).

${ }^{14}$ For Austria's R\&D and technology policy and its effects see Marin (1995). For a model in which multinational investment is motivated to avoid a 'war for talent' in the home labor market, see Marin and Verdier (2003, 2004), see the appendix for the effects of a R\&D subsidy.
} 


\section{Table 11. High Skill Jobs of Austrian Affiliates in Eastern Europe}

\section{University and College Graduates}

(1)

Affiliates' High

Skill Personnel Ratio ${ }^{1)}$
(2)

Affiliate to Parent Skill Ratio $^{2)}$

\section{R\&D Personnel}

(1)

(2)

Affiliates' Rơ Affiliate to Parent Personnel Ratio ${ }^{3)}$ R\&D Personnel Ratio ${ }^{4)}$

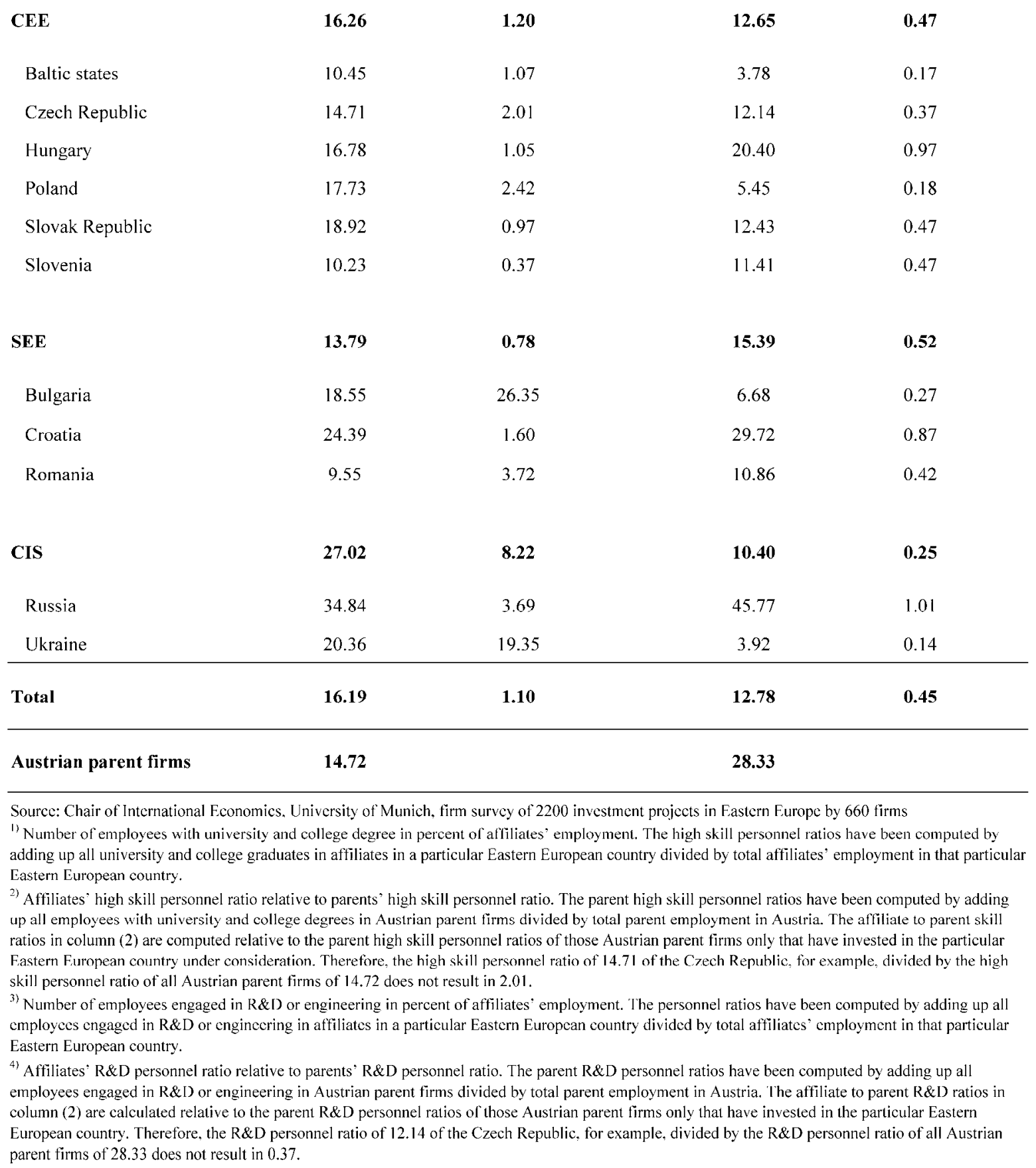


These are striking and puzzling numbers. German and Austrian multinationals tend to outsource the most skill and R\&D intensive activities to Eastern Europe. Why is this happening? Economic theory guides us to look at the factor endowment of these countries for an answer. If countries outsource the most skill intensive activities to other countries, then these countries must be poorly endowed with skills relative to their trading partners. ${ }^{15}$ Table 12 documents Germany's and Austria's endowment with skills compared to Eastern Europe. It appears from the table that the Baltic States, Russia, Hungary, and Bulgaria are the most skill rich countries as measured by the share of the labor force with a tertiary education level. Germany's education level lies below the OECD average and roughly matches that of the accession countries average. In particular, Germany is less skill rich than the Baltic States, Russia, and Hungary. In this ranking of countries Austria turns out to be the most skill poor country. ${ }^{16}$

\footnotetext{
${ }^{15}$ For a theory of multinational investment based on factor endowment differences between countries, see Helpman (1984).

${ }^{16}$ These numbers do not say much about the quality of education in these countries. The numbers are quantitative measures of formal education only.
} 


\section{Table 12. Skill Endowment of Selected Countries}

education levels in percent of the labour force (1998)

\begin{tabular}{|c|c|c|}
\hline & high skill $^{1)}$ & low skill $^{2)}$ \\
\hline OECD high income countries ${ }^{3)}$, average & 0.156 & 0.779 \\
\hline Austria & 0.065 & 0.912 \\
\hline Germany & 0.147 & 0.759 \\
\hline France & 0.237 & 0.763 \\
\hline Sweden & 0.125 & 0.716 \\
\hline Finland & 0.124 & 0.784 \\
\hline Netherlands & 0.255 & 0.743 \\
\hline United Kingdom & 0.147 & 0.749 \\
\hline Italy & 0.096 & 0.895 \\
\hline Norway & 0.174 & 0.691 \\
\hline Japan & $0.186^{4)}$ & $0.712^{4)}$ \\
\hline$C E E^{5)}$, average & 0.135 & 0.738 \\
\hline Baltic States & 0.195 & 0.589 \\
\hline Czech Republic & 0.105 & 0.895 \\
\hline Hungary & $0.156^{6)}$ & $0.844^{6)}$ \\
\hline Poland & 0.114 & 0.852 \\
\hline Slovak Republic & 0.110 & 0.573 \\
\hline Slovenia & 0.071 & 0.857 \\
\hline $\mathrm{SEE}^{7)}$, average & 0.091 & 0.853 \\
\hline Bulgaria & $0.124^{8)}$ & $0.824^{8)}$ \\
\hline Romania & 0.080 & 0.875 \\
\hline Croatia & 0.101 & 0.830 \\
\hline Russia & $0.178^{91}$ & $0.494^{9)}$ \\
\hline $\begin{array}{l}\text { Source: International Labor Organization } \\
\text { 1) tertiary education (third level, first stage, leading t } \\
\text { leading to a post-graduate university degree); Intern } \\
\text { 2) no schooling + first level + second level, first stag } \\
\text { (ISCED-76) } \\
\text { 3) Austria, Germany, France, Sweden, Finland, Neth } \\
\text { 4) } 1997 \\
{ }^{5)} \text { Hungary, Czech Republic, Poland, Slovakia, Slov } \\
\text { (6) } 1999 \\
\text { 7) Bulgaria, Croatia, Romania } \\
\text { 8) } 1992 \\
\text { 9) } 1996\end{array}$ & $\begin{array}{l}\text { ity degree or equivalen } \\
\text { Classification of Educ } \\
\text { l, second stage; Interna } \\
\text { Kingdom, Italy, Norwa } \\
\text { Estonia }\end{array}$ & $\begin{array}{l}\text { I, second stage, } \\
\text { ion of Education }\end{array}$ \\
\hline
\end{tabular}


What has happened to the two countries, Austria and Germany, world famous as the "nations of poets and thinkers' that both rank so low among the rich OECD countries? To understand why Germany and Austria fare so poorly in an international comparison of skill endowment levels, we have to turn to history on the one hand and to the accumulation of skills in the post war period on the other.

I have estimated in Marin (1995) that World War II and the mass killing of jews in the holocaust has destroyed 30 percent of Austria's human capital stock. A less conservative estimate by Stadler (1987) which includes the jewish population which were not members of jewish communities as well as the skilled non jewish population which went into exile range the loss of Austria's human capital stock at 67 percent. Most efforts in Austria in the post war period went into rebuilding the physical capital stock destroyed by World War II. But Austria never recovered from the destruction of its human capital stock, as the accumulation of skills in the post war period has not been able to make up for it. ${ }^{17}$

In Tables 13 and Table 14 I look at the accumulation of skills in the post war period in the two countries. Table 13 reports the annual growth rates of the human capital stock per person in the two countries for the period 1960 to 1997. This measure of human capital is obtained by aggregating five education levels using the market wage of each education level as a weight. The market wage of each education level, in turn, is estimated by a Mincer type wage equation which relates years of schooling to the hourly wage rate. ${ }^{18}$ The table shows that human capital accumulation has dramatically slowed in the 1990s in both countries. In Germany, compared to the 1980s the annual growth rate of the human capital stock per person declined from 0.75 percent to 0.18 percent in the $1990 \mathrm{~s}$. This is a slow down in the growth rate by more than 2/3. In Austria, the annual growth rate of the skill stock more than halved between the 1980s and 1990s from 0.37 percent to 0.15 percent. Unfortunately, the human capital stock data stop in the year 1997. To see what happened after 1997 we turn to Table 14. The table documents that in Germany the share of the labor force with a tertiary education level increased modestly from 11 percent in 1994 to 14 percent in 2000, while this share remained somewhat unchanged in Austria. Thus, in the 1990s when trade integration with the former communist countries and the revolution of information technology both have put pressure on the demand for skilled labor, the supply of skilled labor has almost come to a hold in both countries. This has generated a dramatic scarcity of human capital in both countries.

\footnotetext{
${ }^{17}$ I am not aware of a similar estimate for Germany.

${ }^{18}$ For details on the estimation procedure see Koman and Marin (2000).
} 
Table 13. Human Capital Stock per Person annual growth rates in percent

\begin{tabular}{lcc}
\hline & Austria & Germany \\
\hline $1960-1980$ & 0.45 & 0.85 \\
$1980-1990$ & 0.37 & 0.75 \\
$1990-1997$ & 0.15 & 0.18 \\
$1960-1997$ & & 0.69 \\
\hline
\end{tabular}

Source: Koman and Marin (2000)

Table 14. Skills over Time

Education Levels in Percent of the Labour Force

\begin{tabular}{|c|c|c|c|c|c|c|}
\hline & \multicolumn{3}{|c|}{ Austria } & \multicolumn{3}{|c|}{ Germany } \\
\hline & 1994 & 1998 & 2000 & 1994 & 1998 & 2000 \\
\hline high skill ${ }^{3}$ & 0.06 & 0.07 & 0.07 & $0.11^{3}$ & 0.15 & 0.14 \\
\hline low skill ${ }^{2}$ & 0.94 & 0.93 & 0.93 & $0.71^{3}$ & 0.85 & 0.86 \\
\hline
\end{tabular}

Source: International Labour Organization

' tertiary education

2 secondary education

s 1995

\section{Are 'Maquiladoras' Emerging in Germany and Austria?}

These numbers suggest that the source of the problem is the relative scarcity of human capital in Germany and Austria. German and Austrian firms move the most skill intensive activities to Eastern Europe, because they cannot find the skilled workers in their home labor market. 
The skill move to Eastern Europe may explain why the wage gap between skilled and unskilled workers has remained constant over the 1990s in Germany in spite of the information revolution and trade integration with Eastern Europe.

Figure 2 gives the ratio of skilled to unskilled wages in the 1990s in Germany and Austria on the one hand and in Poland, Hungary and the Czech Republic on the other. We use as a proxy for the skill wage ratio relative wages of non-production to production workers. The data show a strong increase in the relative wage for skills in Poland and the other accession countries during the 1990s, while this ratio remained constant in Germany and declined somewhat in Austria. These data do not show a pattern of factor prices that trade economists usually expect from trade and investment integration. Take the example of Germany and Poland. Typically, when a skill rich country like Germany (relative to Poland) integrates with a skill poor country like Poland (see Table 12), we expect relative wages for skills to go up in Germany and to decline in Poland. The reason is that trade integration leads a country to specialize in those sectors which use the country's abundant factor intensively. Thus, skill rich Germany specializes in the skill intensive sectors and labor rich Poland specializes in labor intensive sectors. As a result the relative demand for skills goes up in Germany and declines in Poland leading to an increase in the relative wage for skills in Germany and to a decline of those in Poland. By the same argument in skill poor Austria relative wages for skills are expected to decline with trade integration with Eastern Europe. 


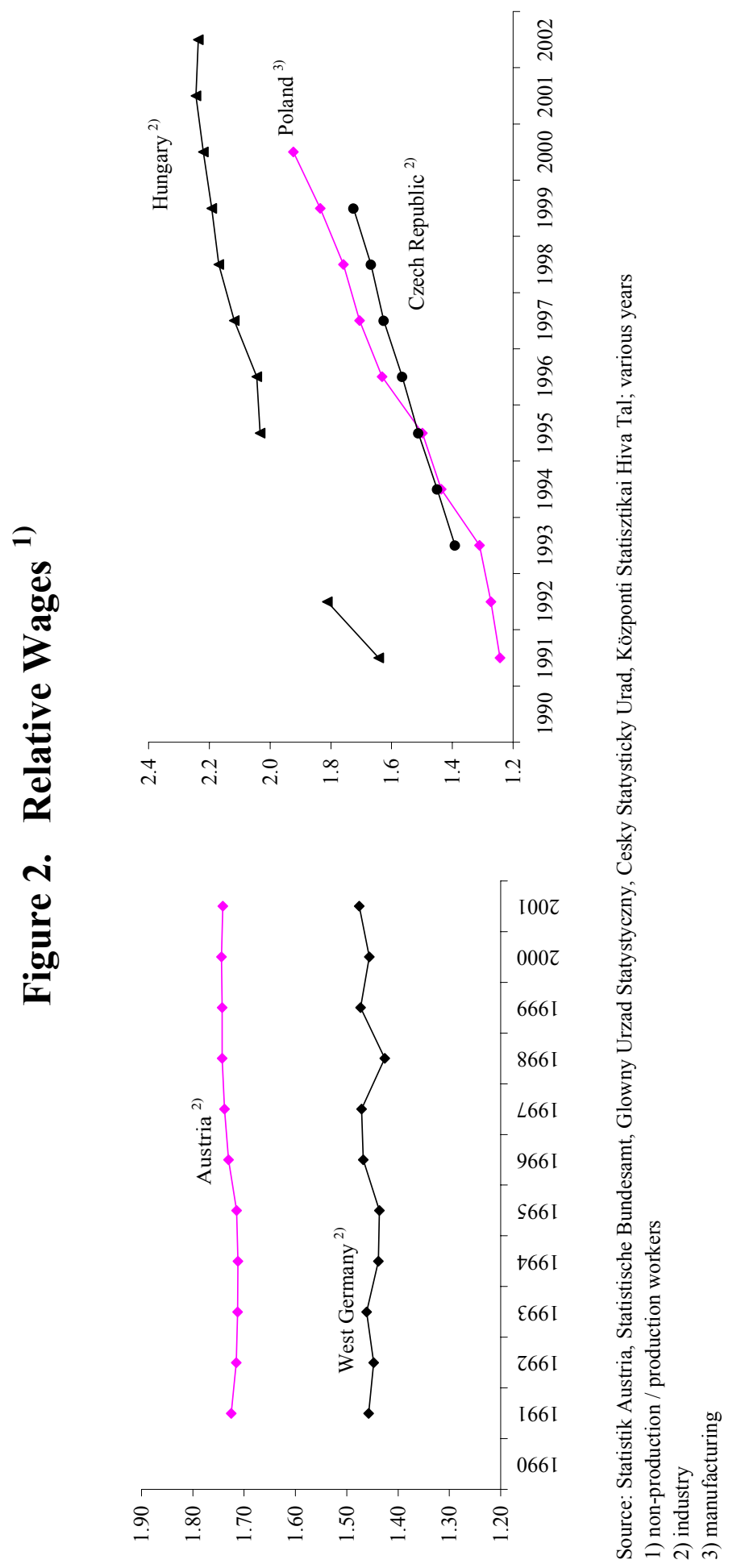


Why have relative wages for skilled workers increased in Eastern Europe and remained constant in Austria and Germany? Why do we observe a perverse Stolper-Samuelson effect in these countries? Economic experts have explained the constancy of the wag gap in Germany and Austria in the 1990s by labor market rigidities. Labor market rigidities may explain why low skilled wages have not declined. But the puzzle remains. Why have skilled wages not increased in Germany and why have they not declined in Austria with trade integration with Eastern Europe? ${ }^{19}$ Lets first focus on Germany. Two easy answers for the constancy of the wage gap in Germany may be obtained from Tables 1, 2 and 12. First, Table 1 and 2 show hat the trade and investment shares with Eastern Europe are too small to have an impact on wage inequality in Germany. ${ }^{20}$ But if this is the answer, why then have trade and investment integration with Eastern Europe not influenced wage inequality in Austria, where these shares are much larger? Second, Table 12 shows that Germany's endowment with skills more or less matches the accession countries' average. Thus, relative factor prices may not have changed in Germany, because Germany's trade integration with the accession countries is an integration among countries with similar factor endowments. But if this is the right answer, why then have relative wages for skills in the accession countries not remained more or less the same as well? ${ }^{21}$ Something else must be at work here.

Feenstra and Hanson (1996) have argued in the context of the North American Free Trade Agreement (NAFTA) that this perverse Stolper-Samuelson effect can be explained by capital movements in the form of foreign direct investment from the US to Mexico. US multinationals started to outsource the more labor intensive stages of production to Mexico. The so called Maquiladoras emerged in Mexico. Maquiladoras are affiliates of US multinationals in Mexico which specialize in the low skill intensive part of the value chain. In their model a single manufactured good is produced from a continuum of intermediate inputs, which are in turn produced using skilled workers, unskilled workers, and capital. Assuming that trade does not lead to factor price equalization, the equilibrium is described by the labor rich South (Mexico) producing and exporting a range of inputs up to some critical ratio of skilled to unskilled labor, with the skill rich North (US) producing the remainder of the inputs. The northern inputs include such activities as R\&D and marketing, which use little or no unskilled labor, while the activities that are more intensive in unskilled labor are outsourced to the South. In this model US multinationals' outsourcing activities to Mexico leads relative wages for skills to increase in the US as well as in Mexico. The reason is that the outsourced activity from the US to Mexico is less skilled labor intensive than what the US is now producing, but more skilledlabor intensive than what Mexico used to produce. As a result relative demand for skilled labor increases in both countries.

The data I have just presented, however, suggest that with Eastern Enlargement an inverse Maquiladoras effect is in the process of emerging in Germany and Austria. German and Austrian multinationals outsource the more skill intensive stages of production to Eastern Europe

\footnotetext{
${ }^{19}$ Fersterer and Winter-Ebner (2003) actually find a slight decline in the return rates on education in Austria.

${ }^{20}$ see Krugman (1994) who argues that the trade shares with low wage countries in the US are much too small to explain the increase in wage inequality in the US.

${ }^{21}$ One could argue that the accession countries' transformation from a planned to a market economy has actually contributed to the increase in the wag gap in these countries. Lorentowicz (2004) finds weak support for this for Poland.
} 
(see columns 2 of Tables 10 and $11^{22}$ ) and specialize in the more labor intensive stages of production in Germany and Austria, respectively. Thus, firms located in Germany and Austria are in the process of becoming the Maquiladoras of German and Austrian affiliates in Eastern Europe with a reversal of roles between headquarter and affiliate activities. The activities transferred by German and Austrian multinationals to Eastern Europe are more skill intensive than those now produced in Germany and Austria, respectively. As a result, the relative demand for skilled labor declines in Germany and Austria. This way, firms' outsourcing of high skill intensive activities to Eastern Europe has helped to ease the human capital crisis in Germany and Austria. ${ }^{23}$ This may explain why relative wages for skills in Germany have not increased with the revolution of information technology in the 1990s as firms' outsourcing activities have removed some of the demand pressure on skills from the German labor market. Whether relative wages for skills increase or decline in Eastern Europe depends on whether or not the outsourcing activities transferred to Eastern Europe are more or less skill intensive than the activities formerly produced in Eastern Europe. The increase in relative wages for skills in Eastern Europe suggest that the activities transferred from Germany and Austria, respectively are more skill intensive than those formerly produced in Eastern Europe. ${ }^{24}$

Is the outsourcing of skill intensive activities to Eastern Europe by German firms economically important? I compute the additional demand for workers with a university or college degree in the local German labor market, that would have arisen when German firms would not have moved the high skill activities to Eastern Europe. We then relate the demand for university and college graduates due to firms' outsourcing to Germany's additional supply of university and college graduates of the 1990s to get a sense of how firms' outsourcing has helped to ease the scarcity of human capital in the 1990s. This is done in Table 15 which quantifies the extent to which firms' outsourcing activity to Eastern Europe has helped to ease the demand pressure on skills in the German labor market in the 1990s.

German firms have created the largest absolute number of university or college degree jobs in the Czech and Slovak Republic, followed by Poland, Hungary and Russia. From the firm survey I estimate that German firms have created a demand of 106.197 skilled workers in Eastern Europe in the 1990s (see column 1 of Table 15). Relating this number to the total number

\footnotetext{
${ }^{22}$ Austrian multinationals in particular to skill rich Bulgaria, Russia, Ukraine, Romania, the Czech Republic and Poland; German multinationals in particular to Bulgaria, the Czech Republic, Russia, and the Slovak Republic.

${ }^{23}$ For a model in which multinational investment is motivated to avoid a , war for talent' in the home labor market, see Marin and Verdier $(2003,2004)$.

${ }^{24}$ In the Feenstra and Hanson (1996) model it is assumed that the US is the skill rich country and Mexico the labor rich country with US firms outsourcing of the labor intensive stages of production to Mexico leading to an increase in relative wages for skills in both countries. Applying this model to Germany and Eastern Europe with Germany as the skill poor country and Eastern Europe as the skill rich country leads to the prediction that German outsourcing to EE leads to a decline in relative wages for skills in both countries. To reconcile the model with the fact that relative wages for skills increased in Eastern Europe one has to assume exogenous differences in technology between the two countries and/or that the activity transferred is more skill intensive than the rest of the recipient economy, see Feenstra and Hanson (1996) for the stability conditions and relative wages. This paper does not attempt to explain the evolution of the wag gap in Eastern Europe. To do so requires a more careful analyses of each particular accession country. For example, Poland's stark increase in the relative wage for skills appears to be induced by outsourcing investments from skill rich countries like France, the US and the Netherlands rather than Germany. For empirical evidence on a Maquiladoras effect in Poland, see Lorentowicz (2004).
} 
of university and college graduates produced in Germany between 1990 and 1997, the demand for skills in Eastern Europe accounts for 12.2 percent of the total supply of university and college graduates produced in the 1990s in Germany (column 2). Assuming that university graduates in the accession countries have 80 percent of the productivity of German university graduates (see Figure 1 which shows that all workers in the accession countries reach 60 percent of the German productivity level), the 12.2 percent translates into a demand for skills in Germany of about 10 percent of the skill supply in Germany. Thus, a skill demand of 10 percent of Germany's additional skill supply of the 1990s has not become effective in Germany due to firms' outsourcing activities to Eastern Europe. At first, this may appear to be a small number. But it is not when Germany's small trade and investment shares with Eastern Europe are taken into account. The number tells us that an investment share with Eastern Europe of around 4 to 5 percent during the 1990s has created a skill demand of 10 percent of Germany's new produced skill supply of the 1990s.

I now turn to Austria. Given the above explanation for Germany, the constant wage gap in Austria still remains a puzzle. In skill poor Austria both trade as well as the outsourcing activities of firms to skill rich Eastern Europe should have led to a decline in relative wages for skills in Austria. Skill poor Austria specializes in the labor and raw material intensive sectors leading to a relative decline in the demand for skills in Austria. What then explains that relative wages remained more or less unchanged during the 1990s? In order to get to an answer I first quantify the skill exodus to Eastern Europe in terms of Austria's additional skill supply of the 1990s. This is done in the left panel of Table 15.

It appears from the table that in Austria the ease on skills due to firms outsourcing of skill intensive activities is much more dramatic compared to Germany. This is not surprising, since Austria is more skill poor compared to Germany (see Table 12) and is much more integrated with Eastern Europe (see Tables 1 and 2). Austria's multinationals are creating a total of 42.233 university graduate jobs in Eastern Europe. The most important destinations of these jobs are Hungary, the Czech and the Slovak Republic. Skill rich Hungary alone is absorbing 23 percent of the total supply of university graduates in Austria in the period 1990 to 1997 (column 2). Assuming a productivity differential between Austrian and Hungarian skilled workers of 20 percent, the outsourcing activity to Hungary alone is reducing the demand for skills in Austria by 18.4 percent relative to the additional supply of skills in the 1990s. An analogous calculation suggests that the demand for skills in Eastern Europe induced by firms' outsourcing activities accounts for $0.8 * 59.7=48$ percent of the additional skill supply in Austria produced in the 1990s. This number suggests that without firms' outsourcing, Austria would have had a 48 percent larger demand for skills in terms of its additional skill supply of the 1990s. According to this computation, relative wages for skills in Austria should have declined dramatically. But they have not. Why?

Here is a possible answer. Government policy may have been contributing to the constancy of the wage gap in Austria. I have argued elsewhere (Marin 1995) that the Austrian government has pursued an active technology policy targeting to increase the share of R\&D as a percent of GDP to the level of other OECD countries. Austria provides generous tax incentives and subsidies to R\&D. Among OECD countries Austria has the largest share of state financed R\&D matching those of the US and France with a large research intensive military sector. Given the 
scarcity of human capital in Austria, this R\&D policy has led wages for skills to go up to absorb the additional demand for skilled workers induced by the R\&D subsidy (for the working of a R\&D subsidy see the appendix). In sum, relative wages for skills may have not declined in skill poor Austria in spite of trade and investment integration with skill rich Eastern Europe because of the technology policy pursued by the government. ${ }^{25}$

In order to take a first look at whether an inverse Maquiladoras effect is indeed at work in Austria we examine now whether annual changes in nonproduction workers' share in the wage bill in Austria is negatively correlated with the share of intra-firm imports from Eastern Europe by Austrian multinationals. We use the nonproduction workers'share in the wage bill as a proxy for the share of skilled workers in the wage bill. I focus on Austria rather than Germany, since Austria has had hardly any outgoing foreign investment before 1989. In 2001 employment by Austrian affiliates in Eastern Europe accounts for 6 percent of Austria's total employment. As a result, intra-firm imports from Eastern Europe by Austrian multinationals in percent of GDP increased rapidly from zero to 3.3 percent of GDP (see Figure A1 in the appendix). Moreover, according to Table 12, Austria is clearly less rich in skills compared to Eastern Europe. Thus, if there is an inverse Maquiladoras effect at work, we should observe it in Austria.

I regress the annual change in the share of nonproduction workers on a constant and on changes in real GDP, on changes in the investment share I/GDP, on changes in the share of R\&D expenditures in percent of GDP, and on changes in the share of intra-firm imports from EE by Austrian multinationals in percent of GDP. The regression is run for the period 1966 to 2001. The data are from Statistik Austria except for intra-firm imports from Eastern Europe by Austrian multinationals which is estimated from the firm survey data (see Figure A1 of the appendix). The coefficient of -0.006 on the share of intrafirm imports from EE is highly significant at the 1 percent level. Multiplying this coefficient by the annual growth rate of 0.125 percent for the share of intrafirm imports from Eastern Europe, we explain about 12 percent of the annual change of 0.006 in the share of nonproduction workers over the period 1966$2001(-0.006 \times 0.125 / 0.006)$. The coefficient of 0.013 on the R\&D/GDP ratio is not significant, so we do not use it to estimate the contribution of technical change on relative wage shares. In any case, these estimates have to be seen as a first look at the data, since with 35 observations there is not enough variation in the data. ${ }^{26}$ But still, according to this regression the rising intra-firm import share from Eastern Europe explains 12 percent of the shift away from non-production labor in Austria suggesting that multinationals' outsourcing of skill intensive activities to Eastern Europe has contributed to the declining prospects of skilled relative to unskilled workers in Austria. ${ }^{27} 28$

\footnotetext{
${ }^{25}$ However, both factors will not explain all of the constancy of the wag gap in Austria given the size of the skill exodus to Eastern Europe. In addition, downward rigidities of skilled wages must be at work as well. Indeed, Austria is witnessing the highest increase in its unemployment rate among university graduates since world war II (see Figure A1 in the appendix).

${ }^{26}$ Unfortunately, at this stage we are not able to estimate the Maquiladoras effect with our firm level data, since we do not observe wages by skills at the firm level.

${ }^{27}$ Feenstra and Hanson (1996) run a similar regression and show that the share of nonproduction workers in the United States is positively and significantly correlated with increasing imports. The rising import share over the period 1979-87 explains 15 to 33 percent of the increase in the nonproduction workers' share. Their estimate is
} 
Table 15. The Scarcity of Human Capital in Austria and Germany

\begin{tabular}{|c|c|c|c|c|}
\hline & \multicolumn{2}{|c|}{ Austria } & \multicolumn{2}{|c|}{ Germany } \\
\hline & (1) & (2) & (1) & (2) \\
\hline & $\begin{array}{c}\text { university and } \\
\text { college graduates } \\
\text { in EE affiliates } \\
\text { (estimate) ' }\end{array}$ & $\begin{array}{l}\text { F.F. affiliates' } \\
\text { skill share }\end{array}$ & $\begin{array}{c}\text { university and } \\
\text { college graduates } \\
\text { in EE affiliates } \\
\text { (estimate) }\end{array}$ & $\begin{array}{l}\text { EF affiliates' } \\
\text { skill share }^{2}\end{array}$ \\
\hline & in persons & in percent & in persons & in percent \\
\hline CEE & 36836 & 52.09 & 103177 & 11.87 \\
\hline Baltic states & 22 & 0.03 & 588 & 0.07 \\
\hline Czech Republic & 14462 & 20.45 & 30195 & 3.48 \\
\hline Hungary & 16123 & 22.80 & 8794 & 1.01 \\
\hline Poland & 1407 & 1.99 & 13392 & 1.54 \\
\hline Slovak Republic & 12653 & 17.89 & 9555 & 1.10 \\
\hline Slovenia & 634 & 0.90 & 207 & 0.02 \\
\hline SEE & 3595 & 5.08 & 8494 & 0.98 \\
\hline Bulgaria & 247 & 0.35 & 478 & 0.05 \\
\hline Croatia & 1451 & 2.05 & 15386 & 1.77 \\
\hline Romania & 1975 & 2.79 & 1050 & 0.12 \\
\hline CIS & 376 & 0.53 & 12900 & 1.48 \\
\hline Russia & 256 & 0.36 & 10566 & 1.22 \\
\hline Ukraine & 222 & 0.31 & 0 & - \\
\hline Total & 42,233 & 59.72 & 106,197 & 12.22 \\
\hline
\end{tabular}

Source: Chair of International Economics, University of Munich, firm survey of 2200 investment projects in Eastern Europe by 660 firms

The data in column (1) are estimated from the university and college graduates in Eastern European affiliates from the survey by correcting for country specific missing values of the data on affiliates' skill levels. The correction assumes that the skill intensity of those foreign direct investments for which information on skills is missing is equal to the skill intensity of the available investments. For Austria we projected the total number of university and college graduates in Eastern European affiliates from the survey information on skill levels of $65 \%$ of the total; for Germany we projected the total number of university and college graduates in Eastern European affiliates from the survey information on skill levels of $31 \%$ of the total.

${ }^{2}$ The Eastern European affiliates' skill share is computed by dividing column (1) by the total number of university and college graduates produced in Austria and Germany, respectively, between 1990 - 1997. The total number of graduates produced between $1990-1997$ is 868,873 in Germany and 70,720 in Austria.

based on 436 observations of four digit SIC industries. They use the total import share including imports of inputs and final goods from independent firms rather than intra-firm imports by multinationals only as we do. ${ }^{28}$ It has been argued that the recent decline of public sector employment due to cost cutting in the public sector has been decisive for the recent sharp increase in unemployment rates among academic people in Austria (see Figure A1 in the appendix). However, we do not find a statistically significant impact of this variable on the wage share of nonproduction workers in Austria. 


\section{What Can Be Done?}

Can an R\&D Subsidy Prevent the Exodus of Skilled Jobs?

The governments in Germany and Austria might be tempted to address the problem of firms' outsourcing of headquarter activity by subsidizing skill intensive activities in Germany and Austria. On December 19, 2003 Chancellor Schroeder declared in the public media that his government will meet the challenge of the loss of high skill jobs to offshore production to low wage countries by creating high skill jobs in Germany. The German labor unions IG Metall ask to make subsidies and public procurement projects contingent on local production Do these policies make sense? Are they desirable for the economy as whole? ${ }^{29}$

A subsidy on high skill intensive activity may as well make things worse when a country is faced with a human capital scarcity. By increasing the profitability of R\&D activity, firms will increase their demand for high skilled labor exacerbating the scarcity of human capital. When the human capital constraint binds, the subsidy will result in a relative increase in skilled wages leading to a decline in manufacturing activity. The reason is that the subsidy induces the R\&D sector to compete with the manufacturing sector for scarce skilled workers pushing up the wages for skills. The expansion of the R\&D sector then crowds out the activity of the manufacturing sector. As a result the manufacturing sector contracts and the country ends up with higher relative wages for skilled workers than before the R\&D subsidy was introduced. This unexpected result of a R\&D subsidy is generated by the economy wide scarcity of human capital. ${ }^{30}$

\section{Liberalize the Movement of Skilled Workers with Eastern Enlargement}

If an R\&D subsidy cannot help what actually can help? If the governments in Germany and Austria care about where these skill intensive headquarter activities take place (and it might make sense to care about it) it needs to find a way to relax the constraint on human capital in the economy. There are two non exclusive ways to do this: to let skills come in from other countries, immigration and/or to produce more skills, education policy. As I have shown in the paper, human capital accumulation has dramatically slowed in the 1990s, in particular in Germany. Therefore, it is important to create an environment in which people find it attractive to invest in human capital. This requires to let relative returns to education to increase by in-

\footnotetext{
${ }^{29}$ See, Süddeutsche Zeitung, September 3, 2003. To get a sense of the crisis felt in Germany consider the new proposal discussed in the social democratic party of government Schroeder. On January 5, 2004 Schroeder declared that he wants to meet the challenges ahead by creating 10 ivy league universities like Harvard and Stanford in Germany. This sounds like revolution for a party with an egalitarian tradition typically opposed to any elitist ideas in particular in education. But the party still opposes tuition fees for students when Tony Blair's labor government is introducing just that in British universities.

${ }^{30}$ For this counterintuitive effect of a R\&D subsidy see Grossman and Helpman (1991) and the appendix. This effect of a R\&D subsidy will be particularly prevalent in small countries with a small number of skilled workers. An example is Austria. The Austrian government pursued an active R\&D policy in the late 1980s and early 1990s with the described unintended results, see Marin (1995).
} 
troducing more flexible labor markets in which relative wages for skills can adjust to changes in market conditions. The PISA study documented that Germany has a problem not only in the quantity of educated people it produces, but also in the quality of education. Education policy is now one of the central policy issues of the German government and rightly so. Focussing on the quantity of human capital produced, Koman and Marin (2000) show that the decline in the growth rate of human capital in the 1990s has come with the costs of 0.5 and 0.3 percentages points less growth annually in Germany and Austria, respectively. These estimates calculate the direct growth effects of human capital but do not take into account potential spillovers to the rest of the economy. If the scarcity of human capital leads corporations to outsource headquarter and R\&D activities to other countries and these activities generate spillovers to the rest of the economy, then the scarcity of human capital may come with growth losses of much larger size than those obtained from a direct growth accounting calculation $^{31} 32$ It is important to note, however, that firms' outsourcing to Eastern Europe leads like any form of economic integration - to an increase in welfare in both Austria and Germany on the one hand and Eastern Europe on the other. ${ }^{33}$

But education policy will take time to change the skill endowment of a country. Immigration is definitely the faster way to deal with a human capital crisis. In Germany the Green Card for IT jobs is the first attempt to bring skills into the country. The German government is now discussing a new immigration law which will govern immigration under European Enlargement. Liberalizing the movement of high skilled labor with Eastern Enlargement would be desirable under this circumstances. The import of skilled workers from Eastern Europe would lower relative wages for skilled workers (assuming labor markets are allowed to adjust) and with it the cost of innovation in Germany. This will make it attractive for firms to undertake these knowledge intensive activities in Germany rather than Eastern Europe.

\footnotetext{
${ }^{31}$ Indirect evidence that the outsourcing activities of German multinationals are producing such spillovers to the rest of the economy is Protsenko (2003). He estimates with the same firm survey data whether vertical and horizontal FDI differ with respect to their spillover effects in the Czech Republic. He finds that German vertical FDI in the Czech Republic has positive effects on the productivity of local firms, while horizontal FDI does not have such effects. This stands in contrast with previous studies on FDI in the Czech Republic which typically find negative productivity effects of total FDI, not distinguishing between vertical and horizontal FDI. These positive spillovers from vertical FDI on a host country casts doubts on the previously held notion that offshore production is a 'bad' thing for an country receiving FDI. What appears to matter here is what kind of firm activity is outsourced to the host country.

${ }^{32}$ Coe and Helpman (1995) estimate international R\&D spillovers and they find that it does matter economically where the R\&D activity takes place.

${ }^{33}$ For the difference between welfare and growth in a global economy, see Grossman and Helpman (1991), for the welfare effects of outsourcing, see Feenstra and Hanson (1996).
} 


\section{References:}

Bourguignon, François, Diane Coyle, Raquel Fernández, Francesco Giavazzi, Dalia Marin, Kevin H O'Rourke, Richard Portes, Paul Seabright, Anthony Venables, Thierry Verdier, und L Alan Winters (2002), Making Sense of Globalization. A Guide to the Economic Issues. Report to the Group of Policy Advisors, European Commission, Centre for Economic Policy Paper No.8, London.

Braconier, Henrik and Carolina Ekholm (2000), Swedish Multinationals and Competition from High- and Low-Wage Locations, Review of International Economics, 8, pp.448-461.

Brainard, Lael S. (1993), A Simple Theory of Multinational Corporations and Trade with a Trade-Off Between Proximity and Concentration, National Bureau of Economic Research Working Paper No. 4269.

Brainard, Lael S. (1997), An Empirical Assessment of the Proximity-Concentration Trade-off between Multinational Sales and Trade, American Economic Review, Vol. 87 (4), pp. 520-44.

Brainard, Lael and David Riker (1997), U.S. Multinationals and Competition with Low Wage Countries, National Bureau of Economic Research Working Paper No. 5959.

Coe, David T. and E. Helpman (1995), International R\&D spillovers, European EconomicReview 39, pp. 859-887.

The Economist (2003), Offshoring: Relocating the back office, $11^{\text {th }}$ December 2003.

Feenstra, Robert C. and Gordon H. Hanson (1996), Foreign Investment, Outsourcing and Relative Wages. In: Feenstra, R.C., G.G. Grossman, and D.A. Irwin (eds) Political Economy of Trade Policy: Essays in Honor of Jagdish Bhagwati. The MIT Press, Cambridge, pp 89-127.

Fersterer, Josef and Rudolf Winter-Ebner (2003), Are Austrian Returns to Education Falling over Time?, Labour Economics, 10 (1), pp. 73-89.

Grossman, Gene and Elhanan Helpman (1991), Innovation and Growth in the Global Economy, MIT Press, Cambridge.

Grossman, Gene and Elhanan Helpman (2002), Integration vs. Outsourcing in Industry Equilibrium. The Quarterly Journal of Economics. 117 (1). pp. 85-120.

Hanson, Gordon H.., Raymond J. Mataloni, and Matthew J. Slaughter (2001), Expansion Strategies of U.S. Multinational Firms. National Bureau of Economic Research, NBER WP 8433, Cambridge. 
Helpman, Elhanan (1984), A Simple Theory of International Trade with Multinational Corporations, Journal of Political Economy, Vol. 92 (3), pp. 451-71.

Helpman, Elhanan and Paul Krugman (1985) Market Structure and Foreign Trade. The MIT Press, Cambridge, MA.

Hofer, Helmut and Karl Pichelmann (2001), Price and Quantity Adjustments in the Austrian Labour Market, Applied Economics, 33, pp. 581-592.

Hummels, David, Jun Ishii, and Kei-Mu Yi (2001), The Nature and Growth of Vertical Specialization in World Trade, Journal of International Economics, 54 (1), pp. 57-96.

Koman, Reinhard and Dalia Marin (2000), Human Capital and Macroeconomic Growth: Austria and Germany 1960-1997, Münchner Wirtschaftswissenschaftliche Beiträge.

Krugman, Paul (1994), Does Third world growth hurt first world prosperity? Harvard Business Review, 72:113-121.

Krugman, Paul (1995), Growing World Trade: Causes and Consequences, $\underline{\text { Brookings Papers }}$ on Economic Activity. 1. pp. 327-377.

Lorentowicz, Andzelika (2004), Foreign Direct Investment and Relative Wages in Poland, University of Munich, mimeo.

Marin, Dalia (1995), Learning and Dynamic Comparative Advantage: Lessons from Austria's Post-war Pattern of Growth for Eastern Europe, CEPR Discussion Paper No. 1116, London.

Marin, Dalia, Andzelika Lorentowicz, Alexander Raubold (2002), Ownership, Capital, or Outsourcing: What Drives German Investment to Eastern Europe? In: Herrmann, Heinz and Robert E. Lipsey (Eds.) Foreign Direct Investment in the Real and Financial Sector of Industrial Countries.

Marin, Dalia and Thierry Verdier (2003), Globalization and the Empowerment of Talent, CEPR Discussion Paper No. 4129, London.

Marin, Dalia and Thierry Verdier (2004), Multinational Investment and the 'War for Talent', University of Munich and DELTA, mimeo.

Markusen, James and Anthony Venables (2000), The Theory of Endowment, Intra-Industry, and Multinational Trade, Journal of International Economics 52, pp. 209-234.

Protsenko, Alexander (2003), Vertical and Horizontal Foreign Direct Investment in Transition Countries, PhD. Dissertation, University of Munich.

Raubold, Alexander (2004), The Economic Geography of Foreign Direct Investment in Eastern Europe, University of Munich, mimeo. 
Sorg, Armin (2000), Erwartungen und Erfahrungen eines Großunternehmers: Das Beispiel der Siemens AG, in: Ökonomische Konsequenzen einer EU-Osterweiterung: eine Veranstaltung der Friedrich-Ebert-Stiftung am 15. Dezember 1999 in Berlin Bonn - Reihe "Wirtschaftspolitische Diskurse“, 131, Bonn.

Stadler, Friedrich (Ed.) (1987), Vertriebene Vernunft, Emigration und Exil österreichischer Wissenschaft 1930-40, Wien: Jugend und Volk. 
Appendix A: Data

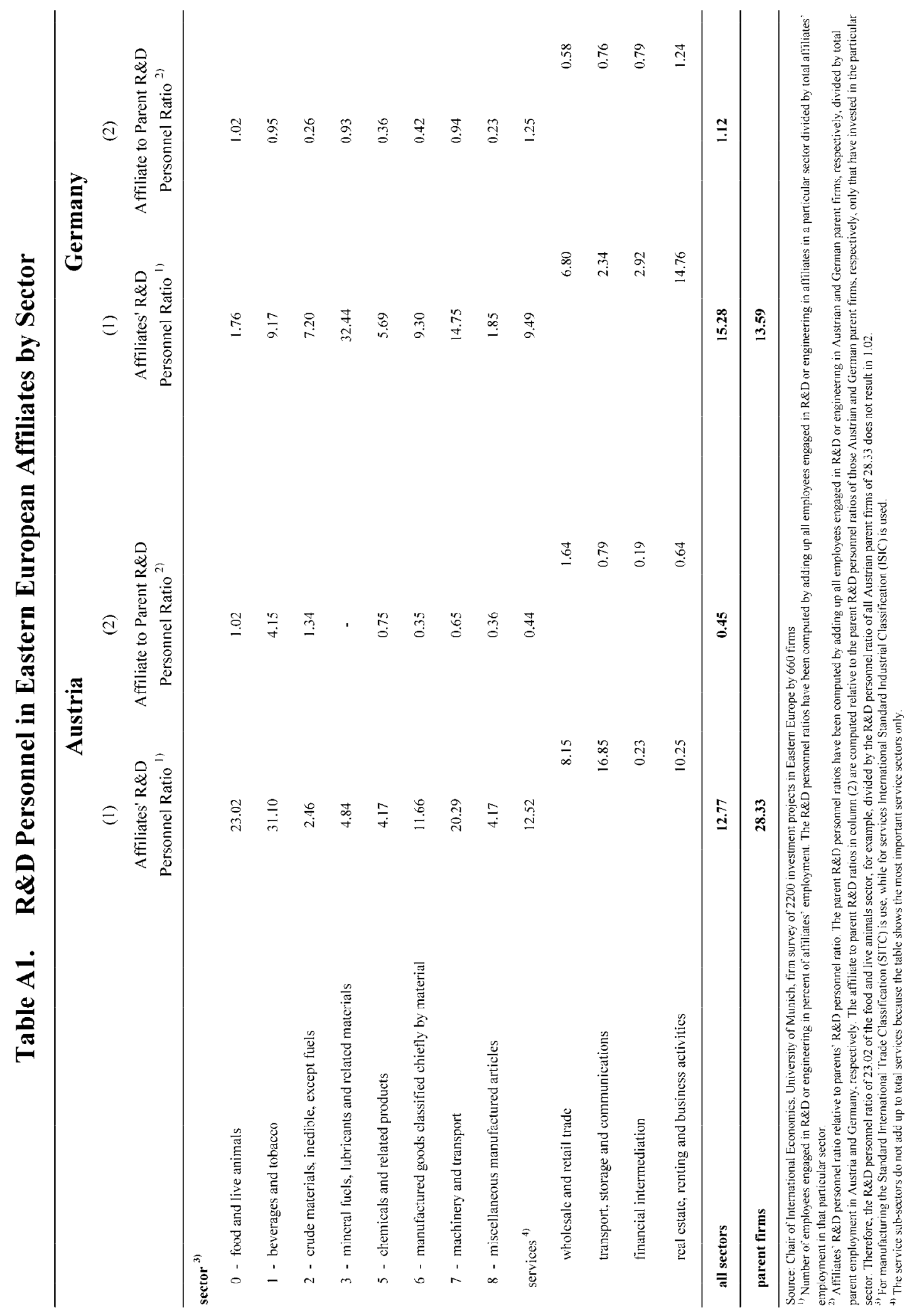



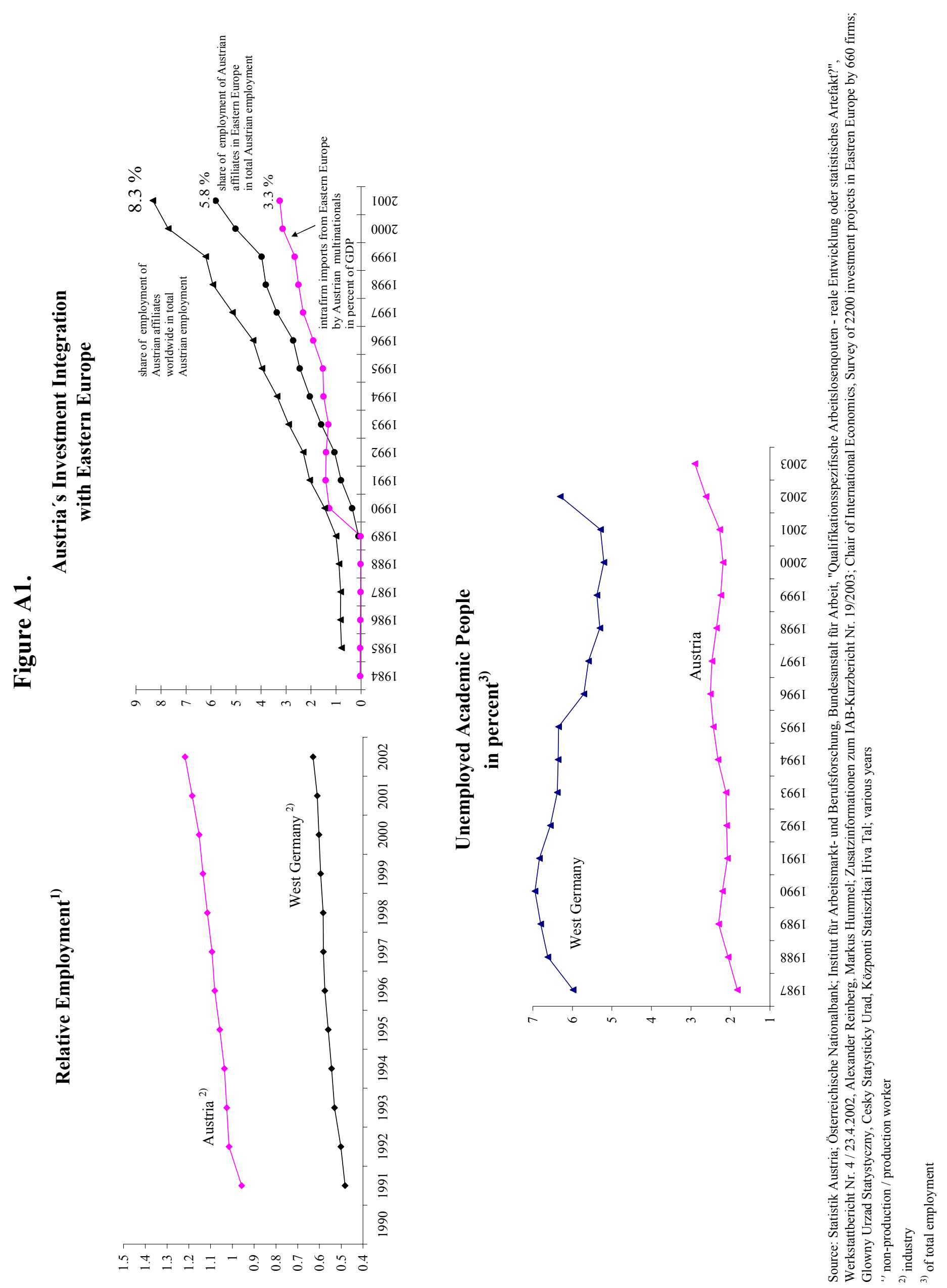


\section{Appendix B: A Subsidy to R\&D}

In this section I want to show how an R\&D subsidy works when a country is faced with a human capital constraint. I use the Grossman and Helpman (1991) model of endogenous growth to illustrate this.

Consider an economy with two sectors manufacturing $X$ and R\&D. Each of these sectors uses human capital as the factor of production. The R\&D sector is developing intermediate goods which are used as inputs in manufacturing. Firms in the manufacturing sector engage in monopolistic competition and produce differentiated goods. Firms are valued according to their expected profit stream. It is assumed that these firms posses indefinitely monopoly power in the particular brand they produce. Firms decide whether to introduce a new brand product by comparing the anticipated stream of profits with expected cost of innovation. These costs depend primarily on the reward of the factor used in R\&D human capital. The profitability of producing these intermediate goods determines the rate at which new products are introduced. The more intermediate goods the R\&D sector produces the higher is the total factor productivity in the manufacturing sector. Hence, a country's growth rate is determined by the speed by which the R\&D sector introduces new brands.

The steady state conditions of the economy are illustrated in Figure A2. The horizontal line gives the innovation rate of the economy $\mathrm{g}$, while the vertical line gives the size of the manufacturing sector $\mathrm{X}$. The line $\mathrm{HH}$ represents the human capital constraint of the economy, while the line NN is the Schumpeter line which captures the notion that innovation is driven by the search for profits. Profits from innovation have to be at least as large as the cost of capital (the interest rate) to maintain the incentive for innovation. HH slopes downwards because an increase in the rate of innovation requires more human capital in research and therefore less human capital is available for manufacturing. NN slopes upwards, because an increase in the rate of innovation raises real interest rates. Therefore, firms require a higher profit rate in order to engage in $R \& D$. To attain a higher profit rate, the manufacturing sector $X$ has to increase and more human capital has to be employed in manufacturing. Point A describes the long run equilibrium.

The figure describes how the growth rate of the economy is constraint by the availability of human capital on the one hand and by market incentives for innovation on the other. For example, a country will innovate less fast when it has a smaller amount of human capital (a contraction of $\mathrm{H}$ shifts in the $\mathrm{HH}$ line) and when its firms have a smaller degree of monopoly power (a reduction in monopoly power shift down the NN line).

Now consider a subsidy to R\&D. This policy has no effect on the human capital constraint $\mathrm{HH}$. It reduces, however, the cost of innovation and as a result it increases the profit rate for a given volume of manufacturing. Therefore the volume of manufacturing has to decline to bring the profit rate back to its equilibrium (profits have to equal the cost of capital). In Figure $\mathrm{A} 2$, an $\mathrm{R} \& \mathrm{D}$ subsidy shifts down $\mathrm{NN}$ to the broken line with the new equilibrium point $\mathrm{B}$. As a result the $R \& D$ subsidy raises the rate of innovation. But at the same time it leads to a contraction of the manufacturing sector. The reason is that by raising the profitability of $R \& D$, 
the R\&D sector expands and competes with the manufacturing sector for the scarce factor human capital. As the human capital constraint binds, wages for human capital go up and the manufacturing sector shrinks to restore equilibrium in the market for skills. The contraction of manufacturing represents the cost of faster innovation.

\section{Figure A2.}

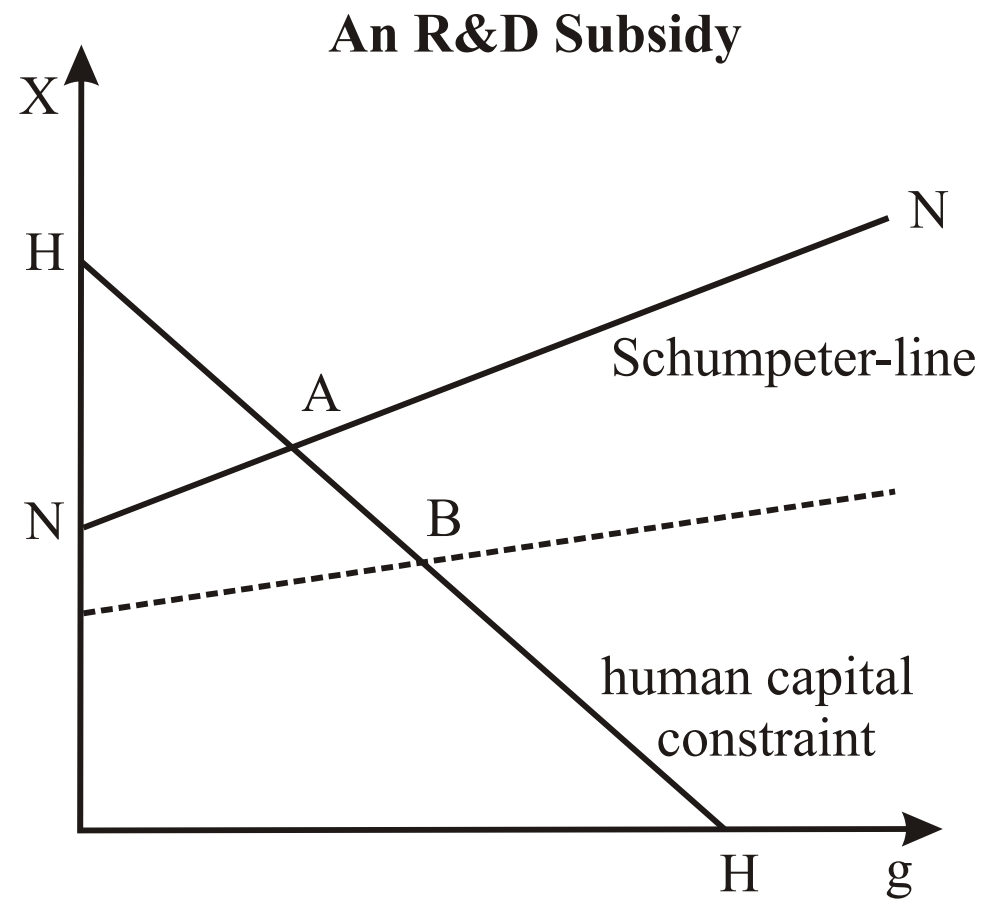

